\title{
LA ASÍ LLAMADA CASA DE HIPPOLYTUS: LA FUNDACIÓN DE LOS ANIOS Y LA SCHOLA DE UNA AGRUPACIÓN COLEGIAL DE LA CIUDAD ROMANA DE COMPLUTUM
}

\author{
SEBASTIÁN RASCÓN MARQUÉS ${ }^{1}$ \\ Ayuntamiento de Alcalá de Henares
}

\begin{abstract}
RESUMEN
El objetivo de este artículo es actualizar los datos existentes sobre la llamada Casa de Hippolytus de Complutum / Alcalá de Henares. El análisis de la documentación aportada por varios métodos (excavación sistemática, estudios arqueobotánicos, zoológicos, historiográficos, etc.) demuestra que se trata de la sede de una agrupación colegial, que se vincula, en un mismo recinto, con un jardín orientalizante y con el mausoleo de la familia de los Anios, la misma que construye la schola de la asociación colegial. Al mismo tiempo refutamos otra interpretación propuesta para este yacimiento, y desechamos que se trate del balneum de una domus suburbana.
\end{abstract}

\section{SUMMARY}

This paper is a review of existent data about Complutum so-called Casa de Hippolytus (Alcalá de Henares - Madrid). A multiple range of documents, belonging to different methods (methodical excavation, archaeobotanic, archaeozoology, historiography), probes that it was a collegia see, bound in the same enclosure with an Oriental garden and with Annios family Mausoleum, the same people who built the collegium schola. At the same time, this paper refute one recent proposal for the site, and refuse the explanation of Casa de Hippolytus as a suburban balneum belonging to a domus.

PALABRAS CLAVE: Termas romanas, collegia, arquitectura privada romana.

KEY WORDS: Roman baths, collegia, Roman private architecture.

\section{INTRODUCCIÓN}

El complejo que nos ocupa, la así llamada Casa de Hippolytus, es en realidad una gran finca compuesta por varias instalaciones, y se encuentra entre un número relativamente alto de edificios que salpican el exterior del casco urbano de la ciudad romana de Complutum por el Norte. En el contexto general de la investigación sobre Complutum hispanorromano, la Casa de Hippoly-

1 Jefe del Servicio de Arqueología del Ayuntamiento de Alcalá de Henares y Profesor de la Universidad de Alcalá. sebasrascon@complutum.com. tus está siendo objeto de intensos trabajos de investigación por parte del Servicio de Arqueología de Alcalá de Henares, de la Universidad de Alcalá y de varios proyectos internacionales, acogidos por la Fundación Dumbarton de la Universidad de Harvard y por la Unión Europea. Pero además, y dado que se musealizó en 1998, se trata de un yacimiento muy conocido por el gran público, y objeto de un intenso trabajo de divulgación.

Tradicionalmente hemos venido defendiendo la interpretación de este yacimiento como la sede de una agrupación colegial complutense, muy probablemente un collegium iuvenum. Nosotros mismos hemos dirigido la excavación de una parte significativa del yacimiento, que en líneas generales se corresponde con los espacios musealizados hasta la fecha, entre los años de 1991 y 1996. Otros elementos, que ayudan a entender esta excavación nuestra, fueron excavados en las dos últimas décadas del siglo XIX, proporcionando materiales que son sobradamente conocidos (Museo Arqueológico Nacional de Madrid). El trabajo que ahora presentamos persigue actualizar nuestros conocimientos sobre el yacimiento y desarrollar la argumentación necesaria para insistir en nuestra interpretación del complejo: la así llamada Casa de Hippolytus es, como intentaremos probar en las páginas siguientes, la sede de una agrupación colegial vinculada a una fundación de la familia de los Anios.

Todo esto nos llevará a presentar una visión parcial del yacimiento, en la que omitiremos interesantes aspectos del mismo que no tendrán cabida en esta publicación, principalmente, el estudio de su cuarta y última fase y su transformación en una iglesia y necrópolis cristianas.

\section{EL CONTEXTO URBANO DE LA CASA DE HIPPOLYTUS: LA CIUDAD ROMANA DE COMPLUTUM}

Este yacimiento arqueológico (fig. 1), incorporado muy recientemente a la literatura científica, está emergiendo como una de las grandes ciudades de la Hispania romana, con unas características arqueológicas y, sobre todo, un tamaño cercano a las $45 \mathrm{Ha}$ de recinto urbano 


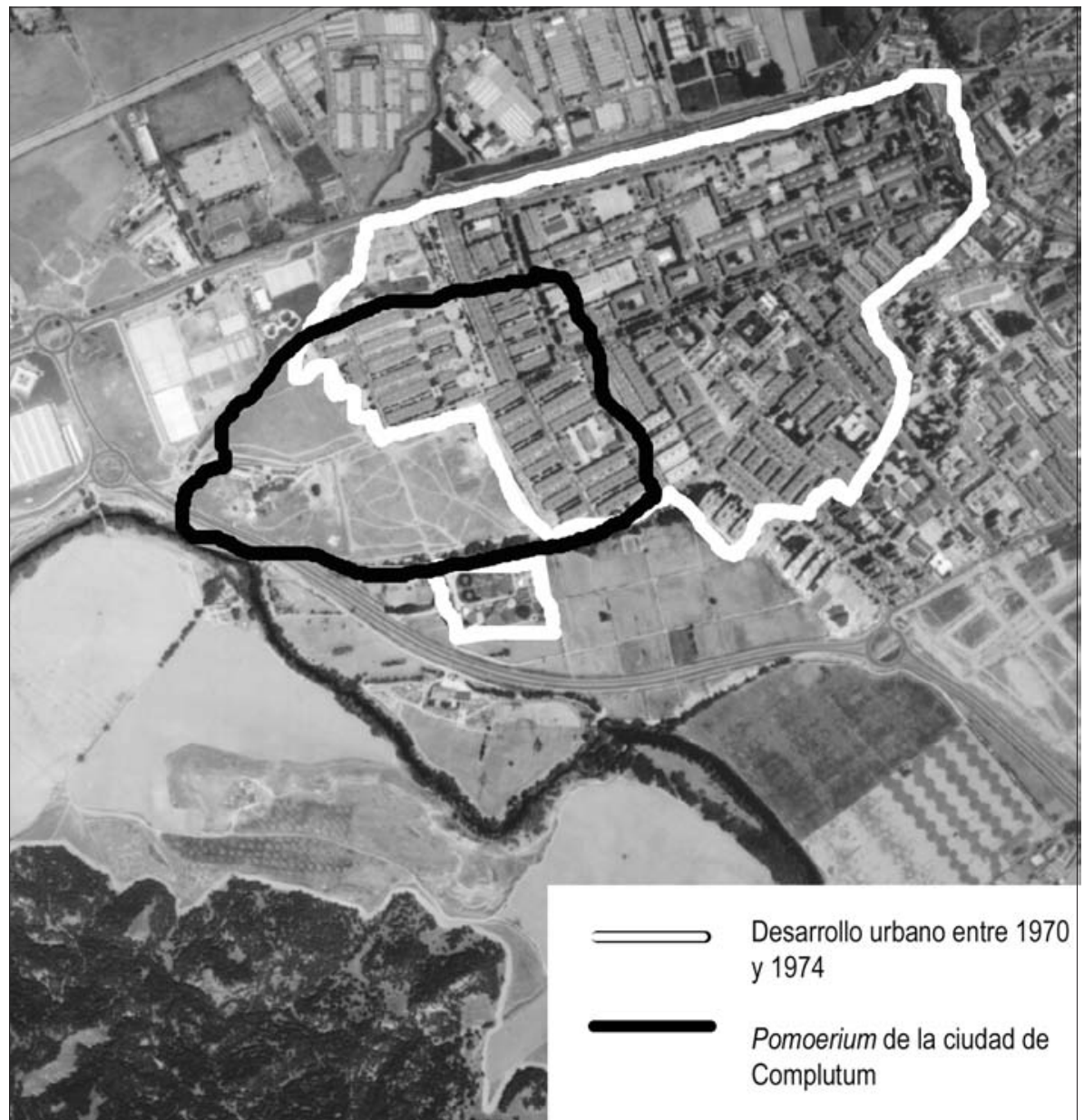

Figura 1. Foto aérea de la ciudad de Complutum y su relación con la actual Alcalá de Henares. Imagen Servicio de Arqueología A.H.

que la aproximan, sin serlo, a las grandes capitales hispanas. Curiosamente sólo en los últimos diez años Complutum alcanza la destacada posición que se merece en el ámbito de la Arqueología Clásica española.

Paradójicamente, Complutum es bien conocida desde el siglo XVI ${ }^{2}$ : en éste, y en el XVII, se realizan excavaciones a cargo de profesores de la entonces célebre Universidad de Alcalá. Se restauran edificios romanos, se celebran procesiones que suponen una cristianización de antiguas ceremonias romanas. Es cierto que esto convive, como en toda España, con una situación más oscura: el expolio de los edificios de la ciudad romana para construir la ciudad medieval y moderna. $\mathrm{La}$

2 Cf. Rascón, 2004, 1, pp. 18-65 y además Vallejo 2005, quien ha realizado una exhaustiva búsqueda de antiguas "excavaciones" arqueológicas, principalmente las desarrolladas en el siglo XIX. existencia de una perla del Renacimiento y Barroco españoles, como era Alcalá de Henares, perjudicó seriamente la conservación de la ciudad romana.

A partir de 1970 la ciudad de Alcalá crece sobre el yacimiento de Complutum, y se produce un redescubrimiento traumático: varias casas privadas son arrasadas, salvándose sólo algunos materiales especialmente notables. Desde los años 80 y 90, el $50 \%$ de la ciudad romana, que no fue arrasada en el crecimiento de la década anterior, se beneficia de una reacción de la ciudad ligada a la recuperación de su carácter histórico, de su patrimonio en general y, claro, de su ciudad romana ${ }^{3}$.

3 La mayor virtud de este método ha sido la transformación de la Arqueología en un elemento más de la realidad social de la moderna Alcalá. Al respecto cf. Sánchez Montes (2000), en el marco de los Congresos de Musealización de Yacimientos Arqueológicos, que las ciudades de Alcalá de Henares y Barcelona organizan desde el año 2000. 


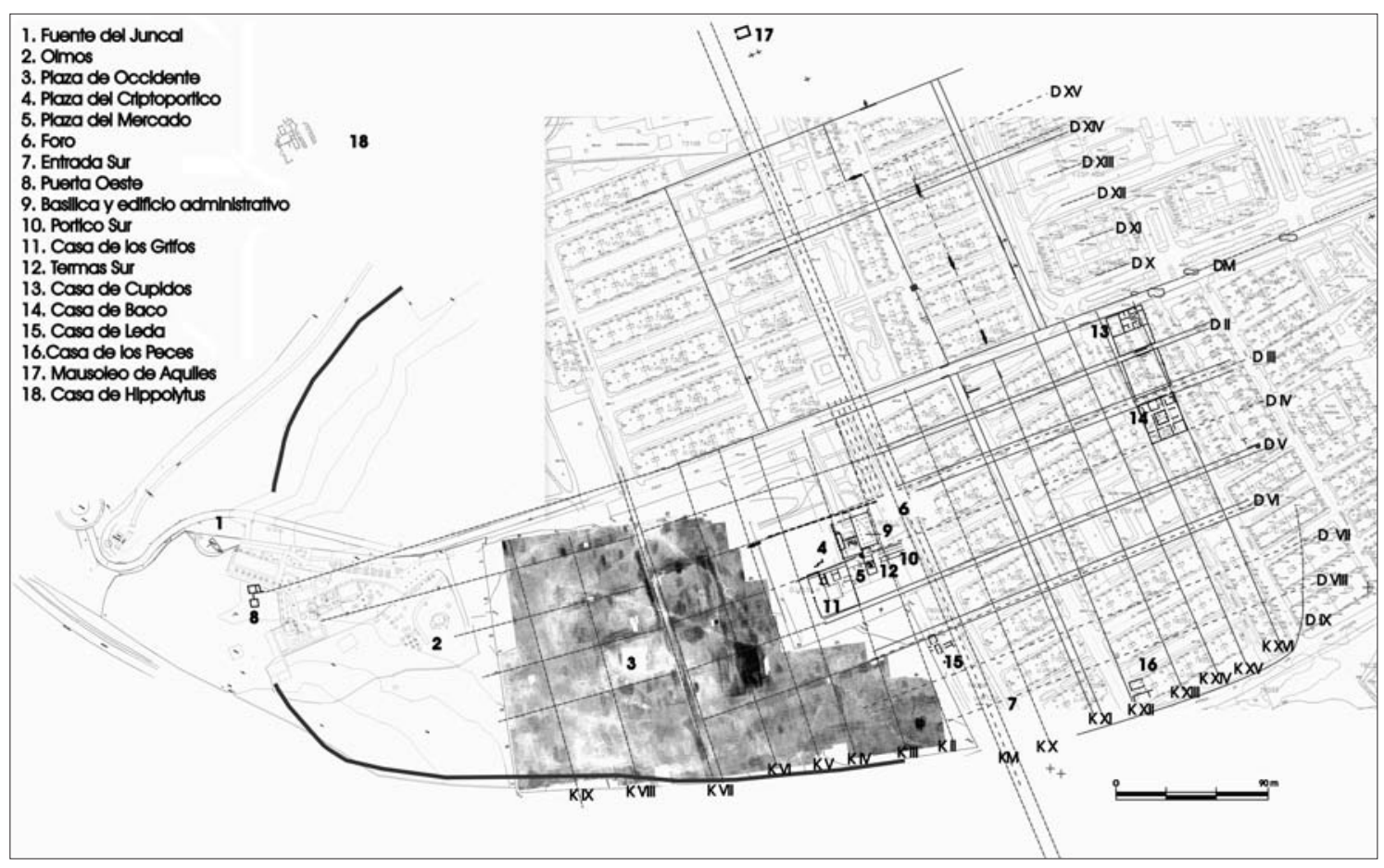

Figura 2. Hipótesis de la trama urbana de Complutum, a la luz de los diferentes datos arqueológicos (extracto de Rascón, 2004).

Respecto a la caracterización urbanística de Complutum es mucho lo que sabemos hoy en día ${ }^{4}$. De hecho, su trama urbana se encuentra entre las diez mejor conocidas de ciudades españolas. Partimos de conocimientos difusos sobre los complutenses prerromanos, adscritos al grupo étnico de los carpetanos: los datos disponibles indican su presencia en el Cerro de San Juan del Viso, en la margen izquierda del río Henares y a escasa distancia del Complutum romano. Esta ciudad se romaniza, y el proceso de cambio cultural se consolida con la construcción de una ciudad de nueva planta en la vega del río Henares, en dos fundaciones, una en época de Augusto, en las dos primeras décadas del siglo I d.C., otra en los años 60 de la misma centuria, sancionada con el rango municipal en época Flavia mediante el célebre Edicto de Latinidad de Vespasiano.

Mediante una compleja y variada metodología, donde destacan el desarrollo sistemático de excavaciones preventivas en la moderna ciudad y la aplicación de prospecciones geofísicas, es posible conocer el urbanis-

4 Proponemos un plano actualizado del urbanismo de la ciudad. Aparece comentado extensamente en Rascón, 2004, III, pp. 52 y ss., como también en Rascón y Sánchez Montes, 2006. mo de esta ciudad, a pesar de que la mayoría esté aun sin excavar (fig. 2): una ciudad de cerca de $45 \mathrm{Ha}$, con un característico urbanismo ortogonal basado en dos decumanos principales (el decumano máximo y el Decumano III) y un cardo, el máximo. Cuenta con un foro, del que se conoce una basílica civil, de los años 60 / 70 del siglo I, reformada en el III. A esta reforma también se corresponden la curia, construida junto a la basílica sobre unas antiguas termas, un criptopórtico y una fachada monumental: el probable tabularium. La fachada se marmoriza y se decora con un carmen epigraphicum: Poesía muy probablemente virgiliana que conmemora alegóricamente la gran restauración urbana del siglo III.

A esto se añaden las zonas comerciales, entre las que se conoce principalmente el Pórtico Sur: el espacio dedicado al comercio de alto nivel, donde conocemos entre otros establecimientos, una officina destinada a un pintor y mosaicista. También el mercado del siglo I, igualmente reformado en el siglo III.

Finalmente, existe un gran desarrollo de la arquitectura privada: especialmente en los siglos III, IV y V se configura un fenómeno que hemos definido como casa-palacio, donde la función representativa está muy desarrollada, y de la que son buenos ejemplos las Casas de Baco, Cupidos y Leda, y la villa suburbana 


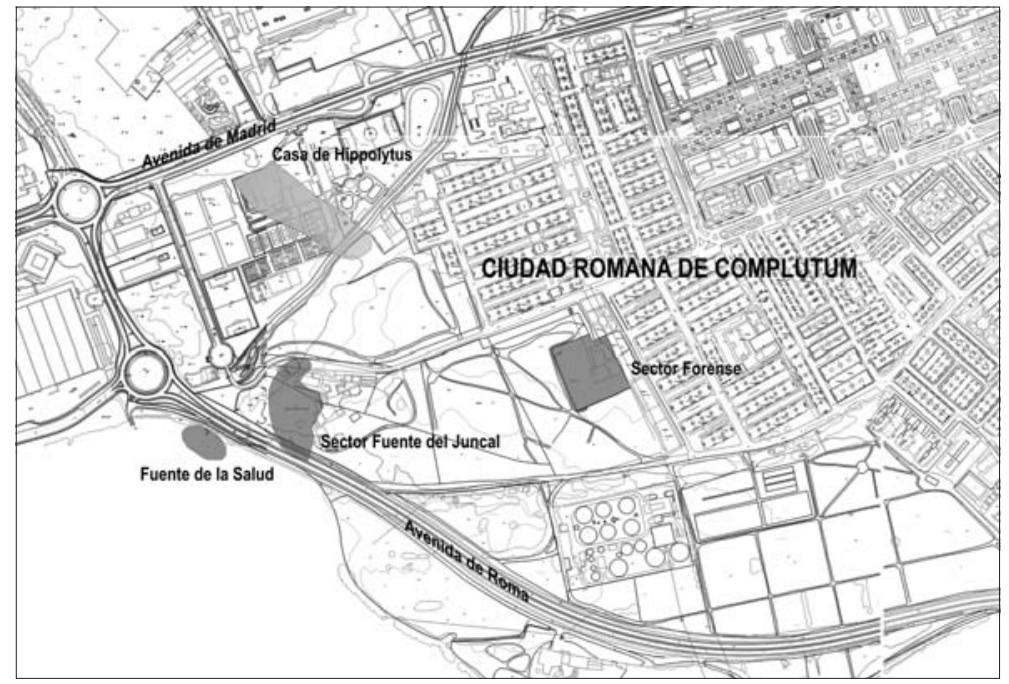

Figura 3. Situación de la Casa de Hippolytus y otros espacios mencionados en el texto. Imagen Servicio de Arqueología A.H.

del Val, con sus magníficas colecciones de mosaicos ${ }^{5}$. Se añaden otros elementos de interés: la Casa de los Grifos, una formidable casa de peristilo del siglo I, que estaba conociendo una profunda reforma a finales del siglo III cuando se incendió por completo. Gracias a esto, y a que no vuelve a levantarse de nuevo, la Arqueología está recuperando uno de los conjuntos de pintura mural más importantes de España. Por supuesto, no puede olvidarse la Casa de Hippolytus, objeto de este trabajo.

Existen otros edificios y espacios de corte industrial y funerario, antaño interpretados de forma general como casas, que hemos ido publicando. Así ocurre con la llamada Casa del Camarmilla, en realidad una fullonica, y la llamada Casa de Aquiles, un mausoleo suburbano ${ }^{6}$.

\section{SITUACIÓN, HISTORIOGRAFÍA Y CONSER- VACIÓN DE LA CASA DE HIPPOLYTUS}

El recinto denominado Casa de Hippolytus se encuentra en los suburbios de la ciudad romana de Complutum, fuera del pomoerium. Se sitúa sobre el estrecho cauce del Río Camarmilla, de forma que la finca se inicia en la margen meridional del riachuelo, y se prolonga hasta al menos $120 \mathrm{~m}$ al noroeste del cauce (fig. 3).

\footnotetext{
5 Los mosaicos son quizá los elementos tradicionalmente mejor conocidos de Complutum. Véase Fernández-Galiano, 1984; Rascón, Méndez y Sánchez Montes, 1998; Rascón, Sánchez Montes, Luna, Polo y Méndez, 1998.

6 Rascón, 2004, II, respectivamente pp. 301 y ss. y pp. 199 y ss.
}

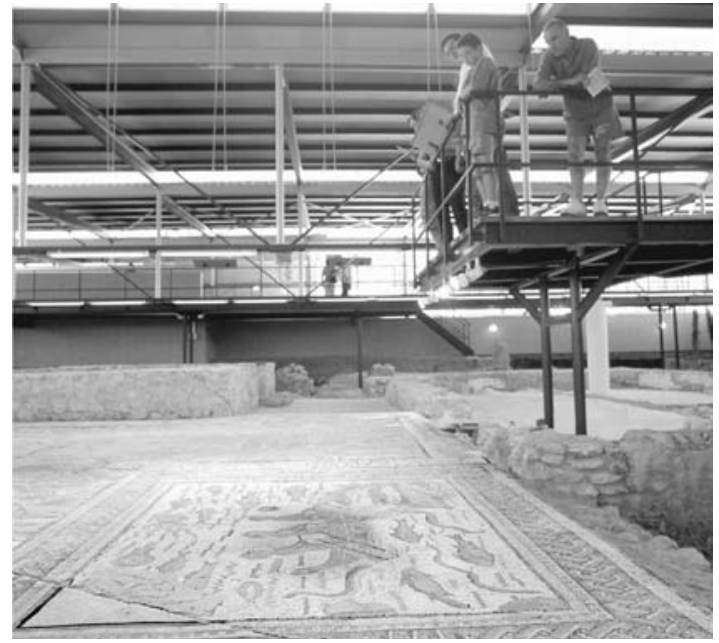

Figura 4. La Casa de Hippolytus, tras su restauración y musealización de 1999. Imagen Servicio de Arqueología A.H.

El edificio se detectó en la realización de la Carta Arqueológica de la Comunidad de Madrid en 1989. Con motivo de las obras de la Segunda Ciudad Polideportiva de Alcalá, se excavó entre 1990 y 1998. Paralelamente se iniciaron las tareas para la restauración. Se desarrollaron campañas de excavación en 1991, 1992, 1993, 1994 y 1996, dirigidas todas ellas por quien firma este trabajo. Además de lo que nosotros mismos hemos adelantado en textos de carácter general ${ }^{7}$, queremos desta-

7 Rascón, 1995: 79 y ss. y 1998b; Rascón, Sánchez Montes, Luna, Polo y Méndez, 1998. 


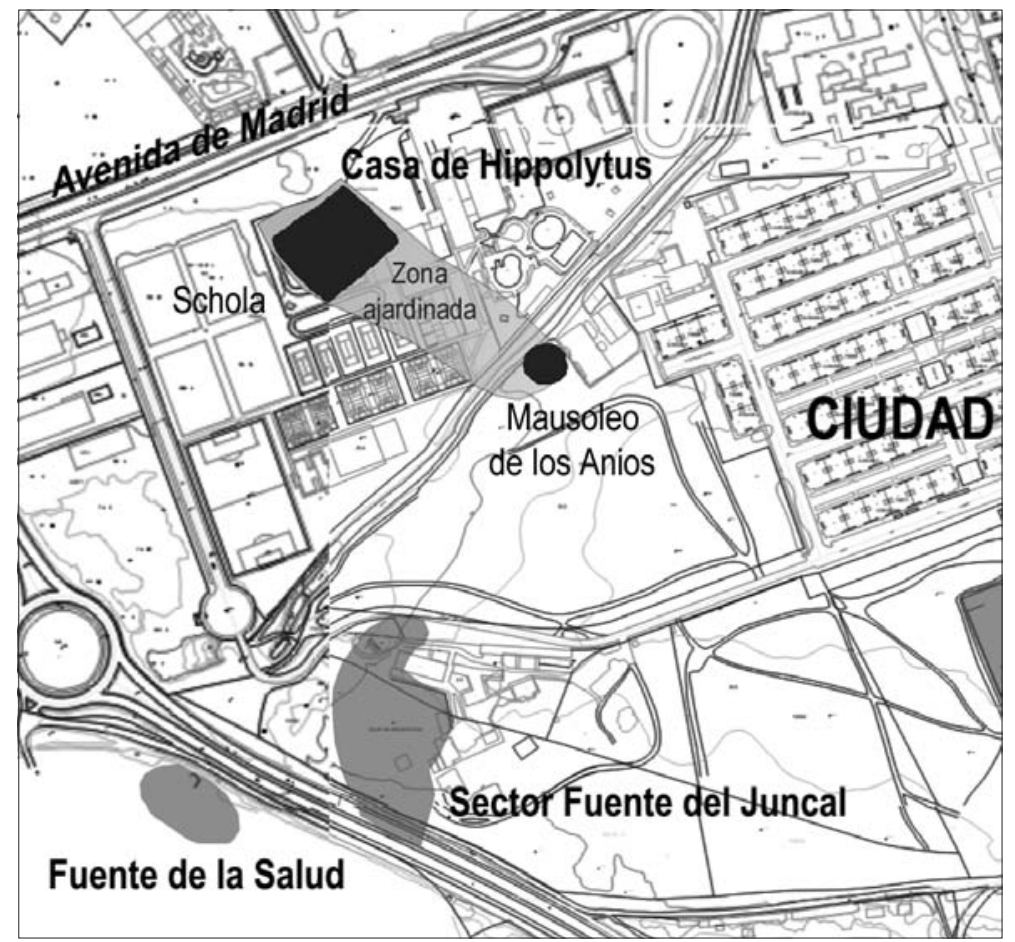

Figura 5. Situación de los tres espacios que componen el complejo fundacional de los Anios (Casa de Hippolytus): schola, zona ajardinada y mausoleo. Imagen Servicio de Arqueología A.H.

car una primera presentación de las estructuras del edificio, principalmente las que permanecían en el siglo IV, así como de su función como schola, en nuestro propio texto de $1996^{8}$. También existe un detallado estudio sobre el mosaico principal $^{9}$, un texto más antiguo de lo que expresa su fecha de publicación, pues fue escrito en 1992 , cuando las excavaciones aun estaban en sus inicios y por tanto algunas de sus conclusiones, sobre todo las hipótesis sobre el edificio y su función, hoy pueden ser cuestionadas, al igual que la lectura original del mosaico y de su cartela, que posteriormente se han revisado $^{10}$.

La Casa de Hippolytus se abrió al público en mayo de 1999 (fig. 4), constituyendo el primer hito visitable de la ciudad romana de Complutum ${ }^{11}$. Se encuentra en un buen estado de conservación, dado que ha conocido un complejo proceso de excavación, restauración y conservación.

\footnotetext{
8 Rascón y Polo, 1996.

9 Rascón, Polo, Gómez Pallarés y Méndez, 1998.

${ }^{10}$ Gómez Pallarés, 2001.

${ }^{11}$ Rascón, 2000.
}

\section{CONFIGURACIÓN ESPACIAL DE LA CASA DE HIPPOLYTUS: LA SCHOLA, EL MAUSOLEO Y EL JARDÍN.}

En realidad, el complejo arqueológico de la Casa de Hippolytus cuenta con tres espacios entrelazados, pero que se delimitan con relativa facilidad (fig. 5):

Primero, en la zona meridional, una zona sagrada, representada por el Mausoleo de la familia de los Anios $\mathrm{y}$ un entorno funerario. Esta zona es la que peor conocemos, porque se excavó en septiembre de 1881, sin criterios metodológicos modernos. Se sitúa sobre la margen sur del estrecho cauce del Arroyo Camarmilla ${ }^{12}$.

\footnotetext{
${ }^{12}$ Los detalles de esta zona se han recuperado recientemente y con bastante detalle (teniendo en cuenta lo precario de la información recogida en una excavación del siglo XIX) gracias al trabajo de Vallejo, 2005, pp. 79 y ss. Pese a ello, muchos detalles son conocidos tradicionalmente, como los materiales exhibidos en un Museo Arqueológico Complutense ubicado en el Archivo General Central, la documentación relativa a los mismos, y las obras remitidas en 1900 al Museo Arqueológico Nacional, donde aún se encuentran, habiendo sido publicadas en varias ocasiones: Marqués de Monsalud, 1899, Knapp, 1992, CIL II 5855
} 


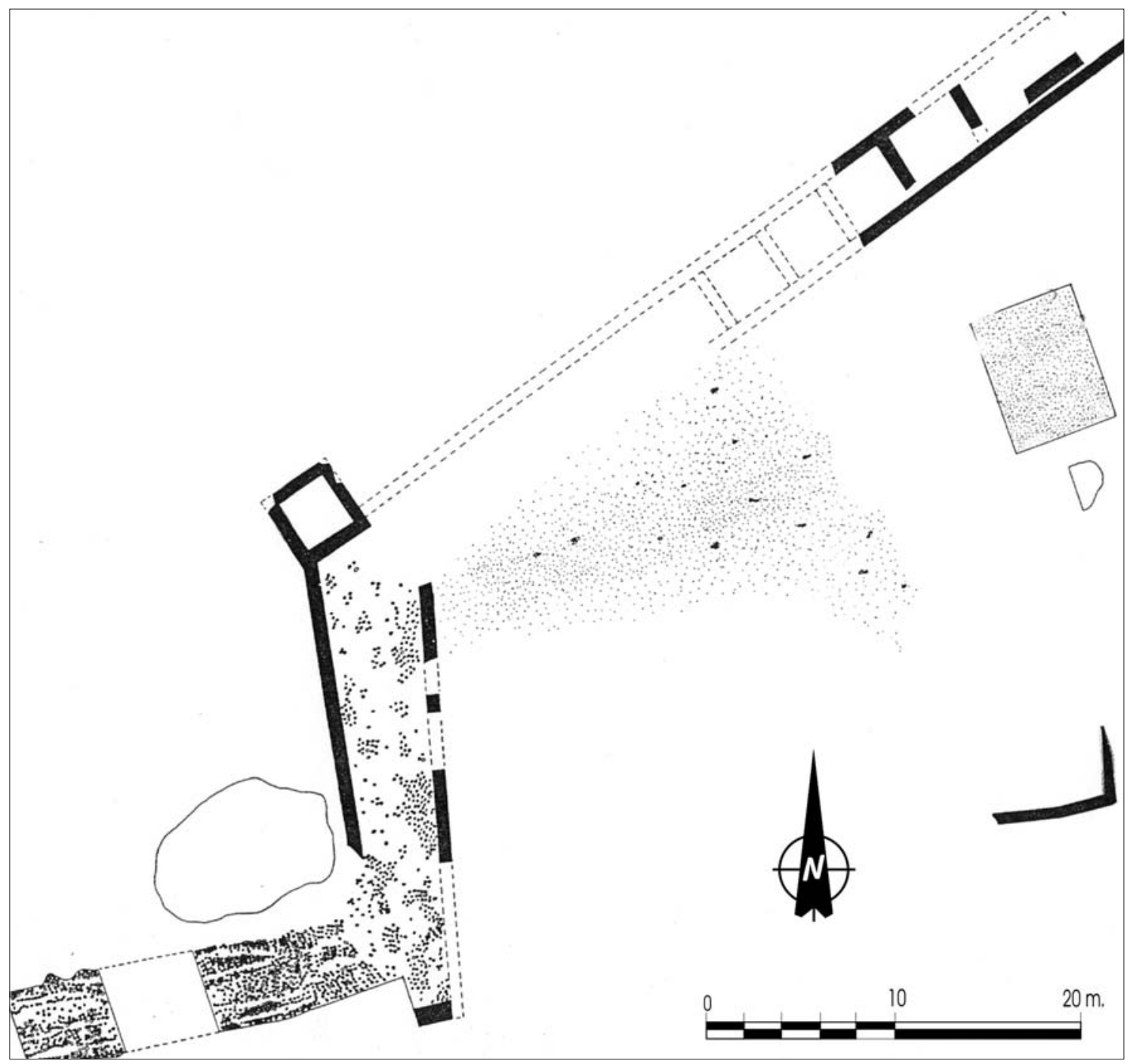

Figura 6. Planta general de la schola en su fase II. Imagen Servicio de Arqueología A.H.

Segundo, en la zona septentrional, y visualmente alineado con el mausoleo, el edificio principal, la schola de una agrupación colegial, mejor conocido por la Arqueología porque fue objeto de excavaciones entre 1991 y 1998, y que coincide con el espacio musealizado y abierto al público hoy en día. Este espacio es el que en general ha sido hasta la fecha objeto de varias investigaciones que pueden encontrarse en la bibliografía especializada, y el que habitualmente se identifica con la Casa de Hippolytus.

Tercero, y uniendo a ambos, un espacio ajardinado cuyas características generales conocemos con bastante aproximación, y sobre el que volveremos más adelante.
Procede que realicemos un breve comentario sobre la ubicación del mausoleo de los Anios y su entorno funerario. La posición que hemos reflejado en el plano que aquí presentamos procede de la interpretación de los textos y dibujos de José Demetrio Calleja, testigo y probablemente partícipe del hallazgo. El conjunto de mausoleo ("Panteón", lo llaman en los documentos de la época), cipos y ara está acotado en el croquis del Sr. Calleja, de forma que el edículo se dispone a 21 pies $^{13}$ $\left(585^{\prime} 06 \mathrm{~cm}\right)$ al sur del cauce del Arroyo Camarmilla (es

\footnotetext{
13 Hemos aceptado un pie de 12 pulgadas, igual a $27.86 \mathrm{~cm}$, y un paso de 1'39 m, (Cortés y Ramírez, 1992).
} 


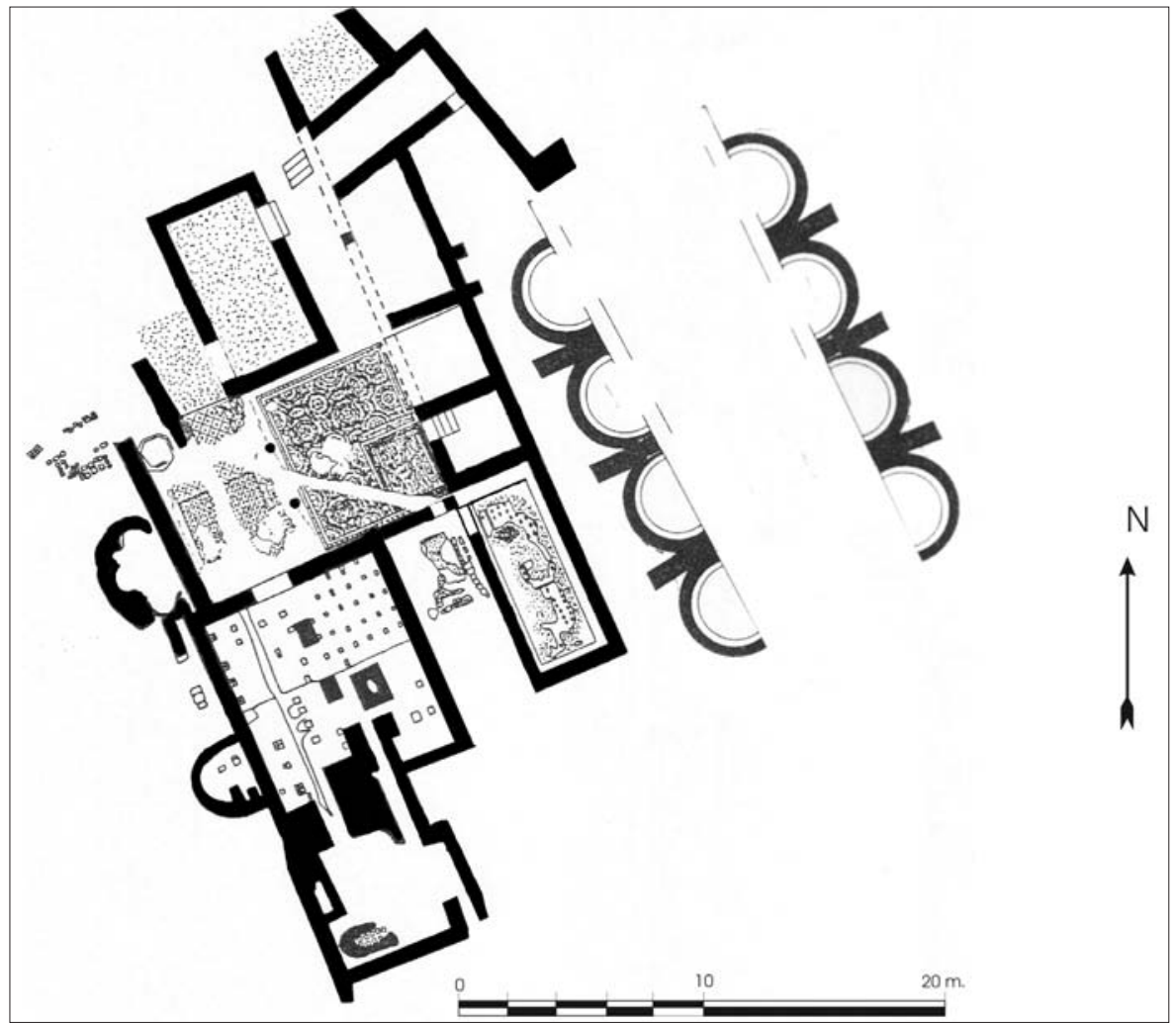

Figura 7. Planta general de la schola en su fase III y principal: detalle de la zona de edificaciones. Imagen Servicio de Arqueología A.H.

decir, casi cabalga sobre la orilla del riachuelo), y a 200 pasos de la Fuente del Juncal. Estos deben interpretarse como $278 \mathrm{~m}$. El resultado de trasladar estas medidas al plano es una posición afrontada en un eje longitudinal con el jardín de los edificios septentrionales y en una cota ligeramente más elevada. El mausoleo, por tanto, se dispone para ser visto desde el edificio termal y jardín de la zona septentrional.

\section{CRONOLOGÍA}

\section{Los edificios de la zona septentrional}

$\mathrm{Al}$ igual que ocurre en la mayoría de los edificios excavados en Complutum, la cronología de las edificaciones septentrionales del conjunto de la Casa de Hippolytus tiene una clara correlación con la del resto de la ciudad: tras una ocupación carpetana, sin construcciones vinculadas, las primeras edificaciones datan de la segunda mitad del siglo I. Conoce una reforma de carácter monumental en relación con el desarrollo de Complutum a finales del siglo III o principios del IV, cuando sobre una estructura urbana que sigue fiel a su diseño original se desarrolla una rica actividad constructiva de la que dan fe los lujosos complejos urbanos y suburbanos. Por último, el espacio se reconvierte en el siglo $\mathrm{V}$ para albergar una necrópolis y una iglesia relacionadas con el culto cristiano.

Las fases documentadas por el análisis estratigráfico lo son en realidad de construcción y no de ocupación: hay un uso continuo de las edificaciones, donde se perciben las obras de rehabilitación o reforma que el edificio va conociendo. La fase I se encuentra muy afectada por las estructuras posteriores. No hay estructuras constructivas asociadas, pero nos parece razonable suponer alguna relación con la fuente de aguas mineralizadas que existe en el yacimiento.

La fase II (fig. 6) se corresponde con la primera fase constructiva hispanorromana. Si bien está muy afectada por la fase III, que es la de mayor envergadura constructiva (nos negamos a usar el término monumentalización) se conservan algunas estructuras indicativas: el camino de acceso a la finca y el cerramiento de la misma por el lado oeste, una fila de estancias de tipo tabernae situadas en el norte de la edificación principal, un pozo y un ver- 


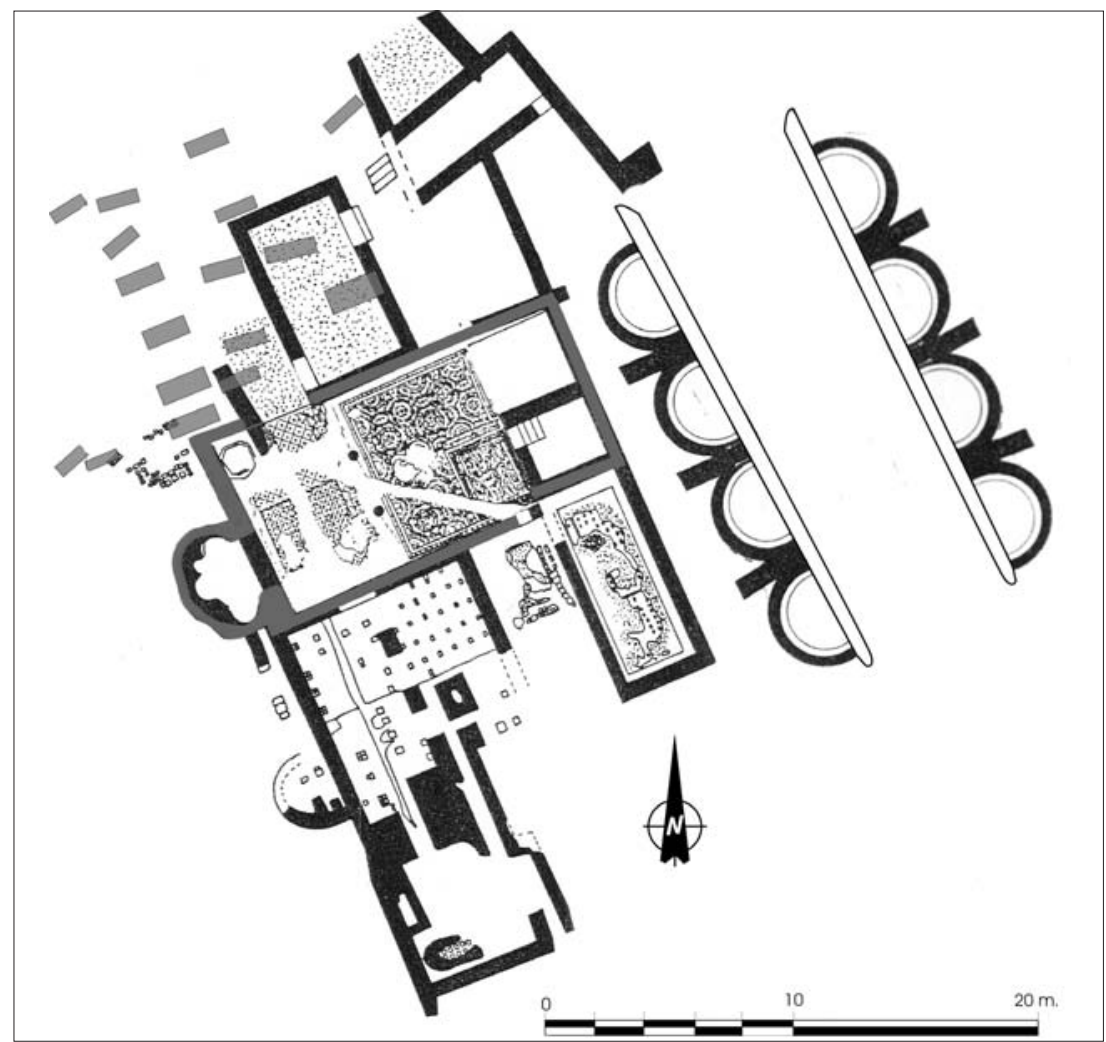

Figura 8. Planta general del edificio en su fase IV y su transformación en iglesia y cementerio. Imagen Servicio de Arqueología A.H. sobre hipótesis de S. Rascón.

tedero. Éste presenta el interés añadido de ser el resultante de la extracción de arcilla para la preparación de los adobes con que se confeccionaría una parte de las estructuras constructivas de la casa; el vaciado luego se rellena con basura generada por sus mismos habitantes, de manera que las unidades estratigráficas inferiores (en concreto la UE 125) cuentan con materiales coetáneos a la primera ocupación hispanorromana de la casa, materiales que fechamos a finales de época julio-claudia e inicios de la flavia, lo que coincide con los años 60 ó 70 del siglo I d.C., y que son los mismos conocidos para la construcción de la ciudad de nueva planta en el llano, en torno a los 60, y la inmediata municipalización del año 74.

La fase III (fig. 7) se corresponde con el aspecto general actual del yacimiento y con la mayor parte de las estructuras que conservamos. Sobre el edificio se desarrolla una intensa reforma constructiva que le confiere una nueva fisonomía. Se embellecen determinadas estancias, decorando los pavimentos con mosaico. Las técnicas edilicias se mejoran adoptando el empleo del opus caementicium, signinum y pseudo vittatum. La cronología de esta fase la aporta el conjunto de estructuras construidas de manera coetánea, y que se fechan sobre todo mediante el mosaico de la sala principal (UE1.111), de las últimas décadas del siglo III d.C.

Por fin, la fase IV (fig. 8) evidencia una serie de modificaciones entre las que hemos de destacar la pérdida de su carácter termal. Algunos espacios se reducen empleando tabiques. La zona central, antes frigidarium y patio central del edificio, se transfigura con las mínimas modificaciones posibles en una iglesia y al mismo tiempo junto a ella se instala una necrópolis de inhumación. Esta transformación se desarrolla a partir de la segunda mitad del siglo IV, en lo que inciden la aparición de cerámicas de tipo TSHt y ARSW, así como el final de la Fase III. Nuestra mejor herramienta para la datación de este final nos la proporciona el análisis de C14 realizado a los restos de madera empleados como combustible en el praefurnium de las termas. Hay que suponer que esta madera, recuperada junto a la boca de uno de los tiros, se cortó para abastecer las necesidades de los últimos momentos de uso del caldarium, y por tanto la fecha de referencia no debe distar demasiado del fin del uso de las termas como tales, y por tanto del inicio de la Fase IV. La fecha del año 1710 +/- 60 BP nos invita a acercarnos a la mas baja de estas posibilidades, 
principalmente porque la rehabilitación del edificio en la fase III se fecha en el último cuarto del siglo III, lo que nos proporcionaría un inicio de la Fase IV en un momento no muy posterior a 350 d. $\mathrm{C}^{14}$.

Aquí finaliza la ocupación del edificio, y después sólo se distinguen una serie de niveles de destrucción de época moderna, relacionados con su expolio.

\section{Las construcciones de la zona meridional}

Por desgracia para fechar estos restos sólo podemos recurrir a las anotaciones y dibujos realizados el 14 de septiembre de 1881 por José María Escudero de la Peña, Jefe del Archivo General Central y Correspondiente de la Real Academia de la Historia. El contenido del texto ${ }^{15}$ y los dibujos son sin embargo suficientes para que consideremos varios elementos funerarios o religiosos claramente altoimperiales: el ara votiva a Hércules y varios cipos funerarios, que han de fecharse (al menos la primera) entre los siglos I y II. Por otro lado los ocupantes principales del edificio del Mausoleo estaban inhumados en sarcófagos de mármol, y rodeados de restos materiales inequívocamente romanos, aunque difíciles de precisar en lo que a datación se refiere. La práctica de inhumación en sarcófago nos lleva a fechas no más altas del siglo III d.C., que podrían extenderse hasta el IV. A pesar de ser datos muy generales, unos y otros nos sugieren, por su concordancia con las fechas propuestas en la zona septentrional, la hipótesis de una evolución paralela para los dos sectores. Ambos estarían ya en funcionamiento en la segunda mitad del siglo I, bajo los designios de la familia de los Anios, que es quien dedica el ara a Hércules. A finales del siglo III se realizaría una gran rehabilitación en los edificios del sector septentrional, y es sugerente pensar que esas mismas actividades edilicias, conmemorativas y evergéticas se plasmarían en el meridional, con la construcción de un mausoleo funerario (no sabemos si nuevo o rehabilitado) que recibiría los restos mortales de los evergetas.

En cualquier caso, nos enfrentamos a un uso religioso, funerario, y por tanto conmemorativo, que se prolonga a lo largo de los mismos siglos en que el edificio septentrional está en uso.

\section{DESCRIPCIÓN}

\section{La fase II}

Las estructuras más antiguas que conocemos pertenecen a la fase II (fig. 6) y se fechan en el tercer cuarto

\footnotetext{
${ }^{14}$ Análisis de Radiocarbono efectuado por Beta Analytic Inc., con fecha 20 de abril de 2001.

${ }^{15}$ Reproducido en Vallejo, 2005, pp. 79 y ss.
}

del siglo I d.C. Nada conocemos de la etapa carpetana, aunque es coherente suponer que existiese un determinado tipo de construcciones que no se han conservado y que la fuente de aguas mineralizadas fuese conocida.

La fase II constituye la base de la III. Por esta razón se define con cierta dificultad, dado que parte de sus estructuras subyacen o se imbrican con las más modernas, aunque se da también el caso de que algunas estructuras son aprovechadas en la fase III, integrándose en la nueva planta del edificio.

Los principales elementos conservados se encuentran en la zona occidental del edificio, constituyen el acceso a la finca por el Oeste, y son un camino de acceso que se configura mediante un doble codo con dos tramos, una fachada que sirve de cerramiento a la finca y sus respectivas entradas. Junto al camino, un vertedero que se configura como un gran cráter de un diámetro de $7 \mathrm{~m}$ en su parte superior, y se relaciona con la extracción de barro para la elaboración de adobes. El camino describe un doble codo, un tramo de orientación NorteSur, que da acceso al edificio, y otro de orientación Este-Oeste, que con el anterior forma un ángulo de $100^{\circ}$. El camino tiene una capa de preparación de cantos rodados de pequeño tamaño, sobre el que se desarrolla una segunda capa de gravas con arena y abundancia de caliza triturada, siguiendo el mismo procedimiento técnico que se documenta en el Foro de Complutum o en la villa suburbana del Val. Además, está delimitado por dos muretes que actúan a modo de bordillos, de cantos cuarcíticos de tan solo dos hiladas de piedras, y de un ancho de $60 \mathrm{~cm}$.

En este lado occidental, el cerramiento de la finca está representado por medio de una fachada con zócalo de piedra y alzado de adobe. La entrada del camino en el recinto coincide con una estructura de planta cuadrangular, también con zócalo de cantos cuarcíticos de las mismas características que el bordillo del camino, y con alzado de adobes (fig. 9), un ornamento arquitectónico que recurre al uso de un elemento turriforme que enmarca el portón principal, poco antes del cual, levemente al Sur, existe una poterna de menor tamaño. El análisis de los restos arqueológicos permiten que aventuremos una hipótesis de reconstrucción tridimensional ${ }^{16}$ (fig. 10):

\footnotetext{
${ }^{16} \mathrm{El}$ avanzado estado de las investigaciones permite que recurramos a este método en casi todas las zonas del edificio. Las hipótesis se han plasmado por medio de la combinación de programas de dibujo asistido por ordenador en dos dimensiones, trasladándose después a otros de modelado tridimensional de probado rendimiento, texturados con materiales recuperados en la propia excavación arqueológica. Se han renderizado mediante el recurso a programas de iluminación hiperrealistas. Todo el proceso lo desarrollaron los equipos de modelado tridimensional del Servicio de Arqueología municipal de Alcalá de Henares.
} 


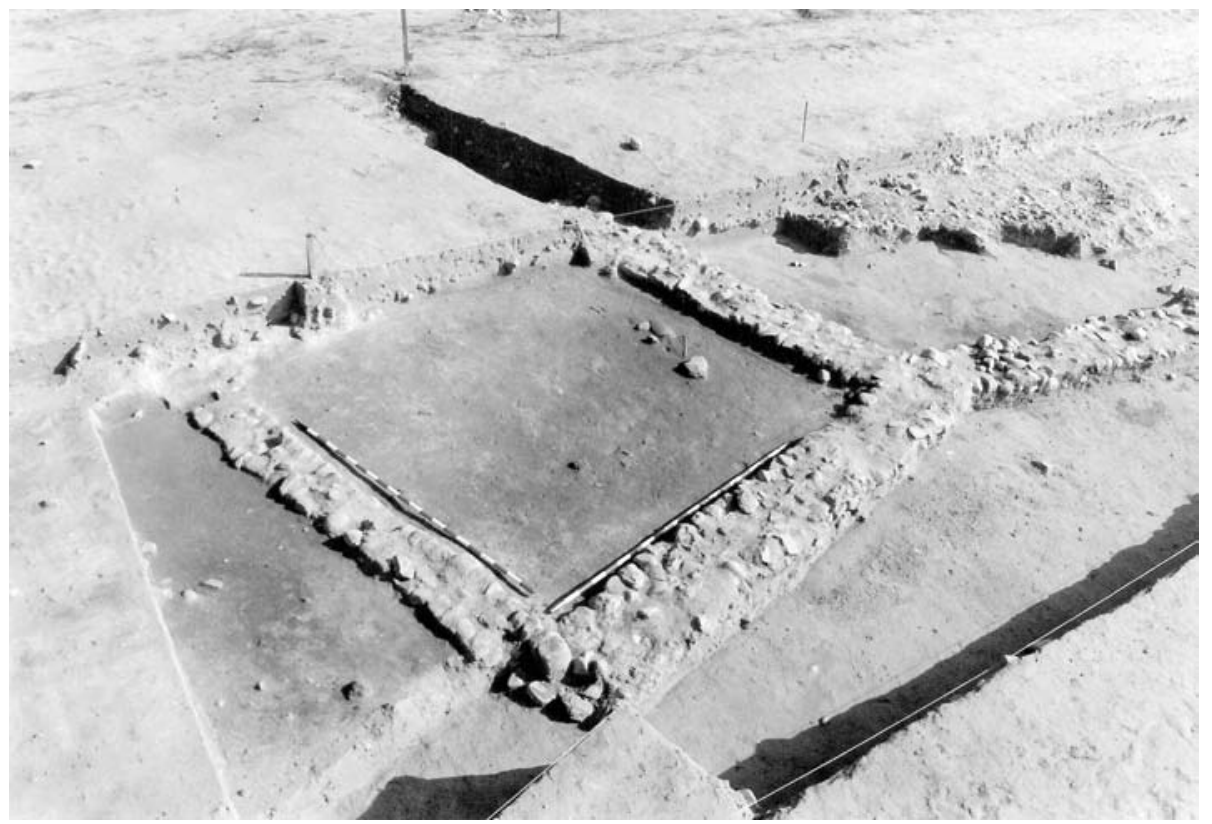

Figura 9. El camino de entrada y la torre que enmarca el acceso al recinto por el Oeste. Imagen Servicio de Arqueología A.H.

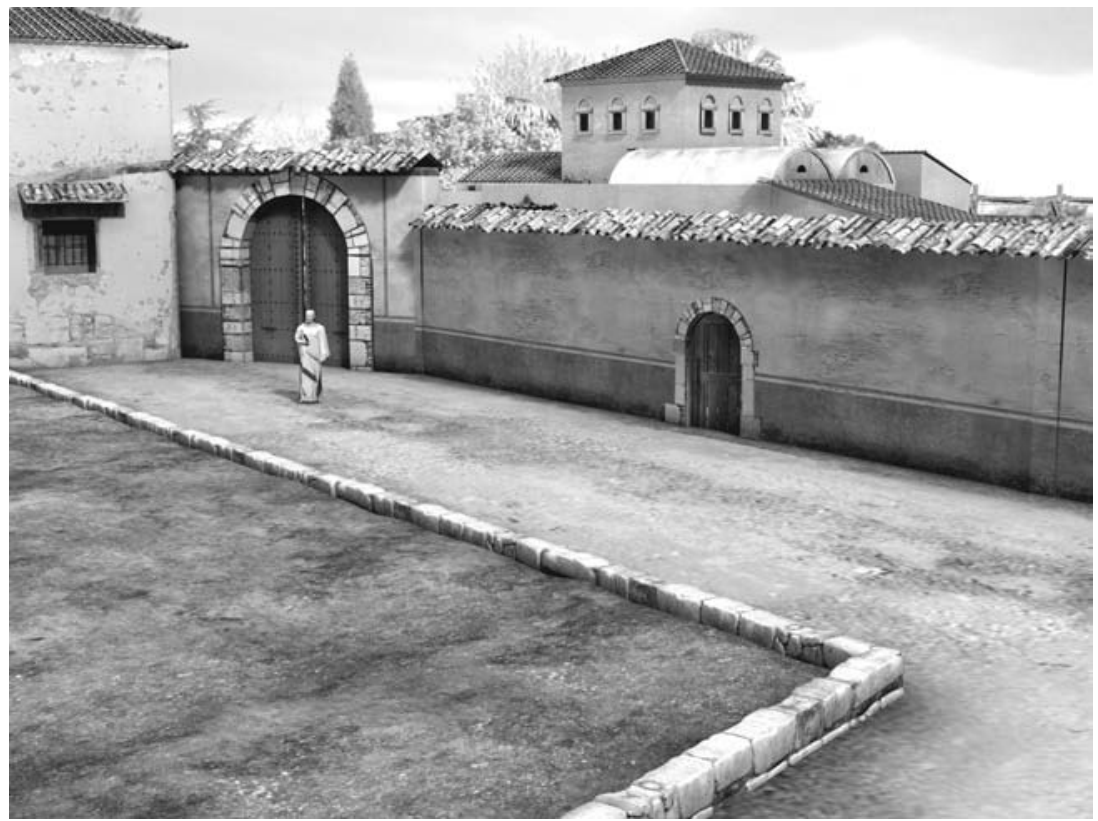

Figura 10. Reconstrucción hipotética del acceso al recinto en función de los datos arqueológicos. Imagen Servicio de Arqueología A.H. sobre hipótesis de S. Rascón. 


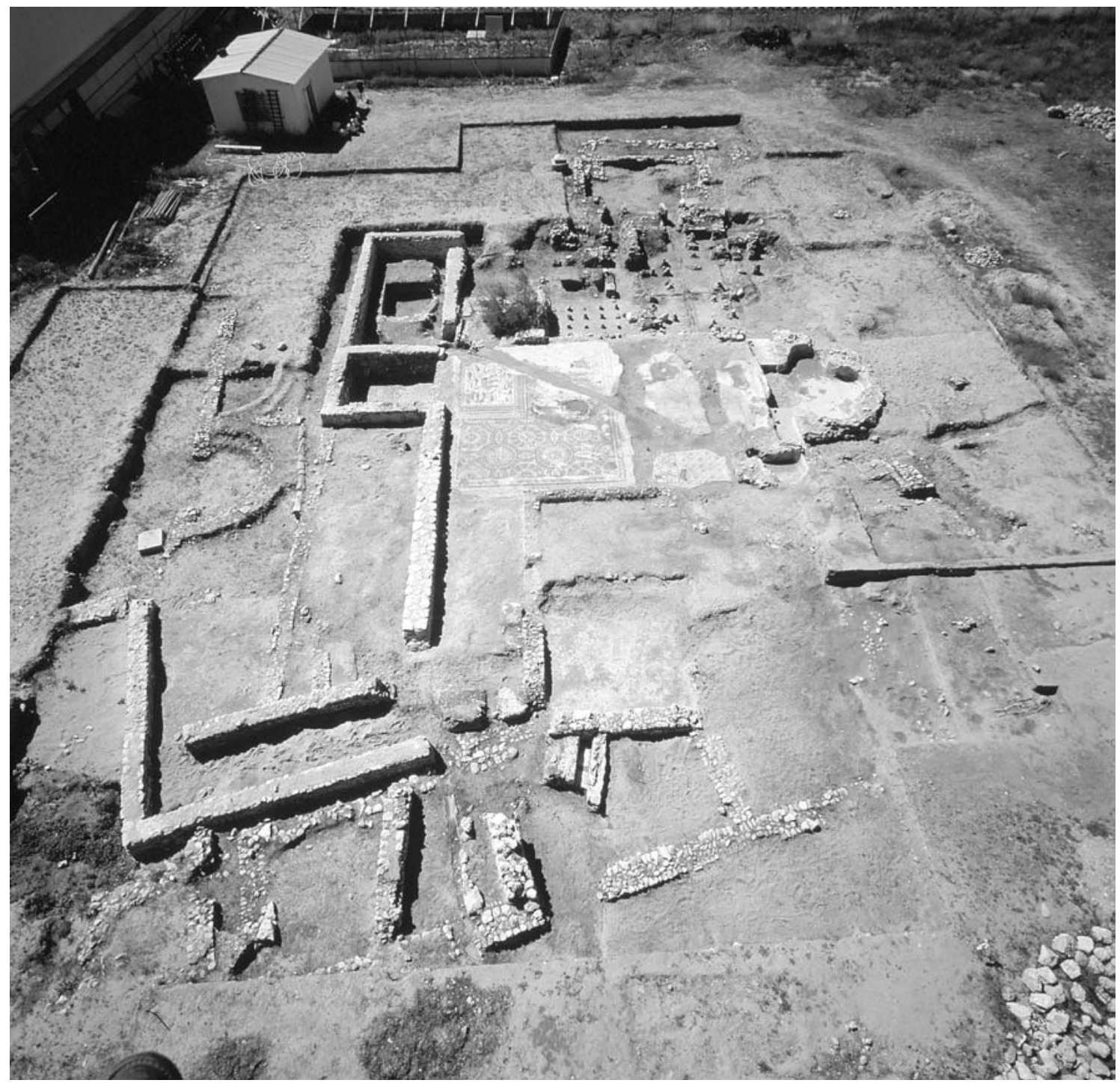

Figura 11. Vista general de la schola durante el proceso de excavación. Imagen cortesía de Lunwerg Editores y Oscar Masats.

A continuación, y antes de llegar al edificio, se extendía un gran patio empedrado de las mismas características constructivas que el camino de acceso. Cerrando el edificio por el Norte aparecen una serie de estructuras alineadas también en dirección Este-Oeste de las que sólo conservamos los zócalos de cantos rodados.

Respecto a la parte central del edificio, las construcciones de la fase III han soslayado casi totalmente las anteriores. No obstante, hay que mencionar el pozo o fuente ubicada en el extremo sur, que estaría ya en uso en esta primera fase. También a esta fase pertenece un pavimento de opus signinum que subyace al mosaico de la estancia central del edificio, y que pavimentaría una estancia más antigua.

\section{La fase III}

En las últimas décadas del siglo III se emprende un intenso trabajo de remodelación del edificio, que altera de forma importante las concepciones arquitectónicas del antiguo complejo de época Julio-Claudia, y que dejará paso a un nuevo espacio (figs. 7, 11 y 12). Este nuevo edificio está más constreñido en el espacio, con tan sólo 640 $\mathrm{m}^{2}$ construidos, que aprovecha únicamente elementos muy determinados de la fase anterior, emplea una obra constructiva variada y, en todo caso, de muy buena calidad, se define funcionalmente como un complejo destinado al ocio donde destaca la función termal, a la reunión y al culto que se decora lujosamente con un buen núme- 


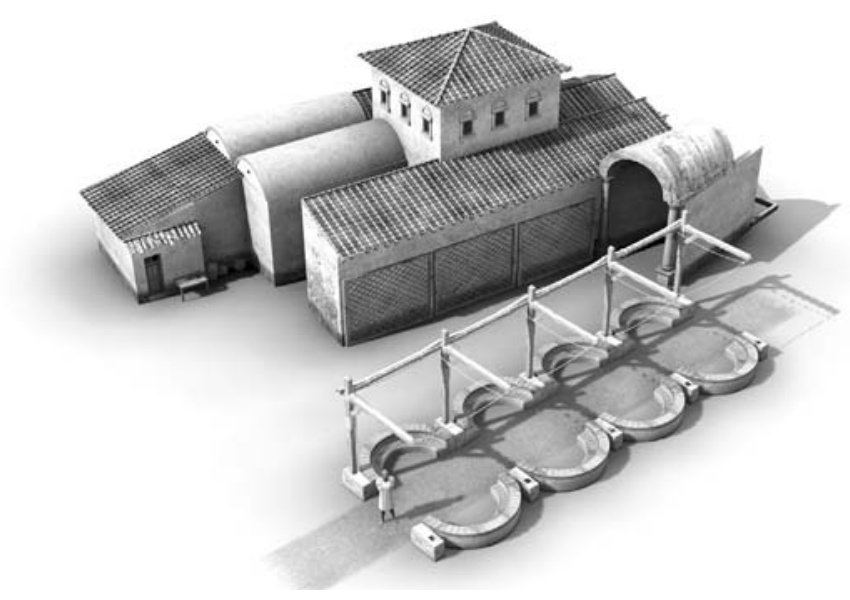

Figura 12. Reconstrucción hipotética del edificio de la schola tras la remodelación de finales del siglo III d. C. Imagen Servicio de Arqueología A.H. sobre hipótesis de S. Rascón.

ro de materiales muy costosos: mosaico, escultura y pintura mural. Además, se desarrolla un espléndido jardín de corte orientalizante, uno de los elementos arqueológicos más importantes del edificio y, como se verá, un unicum de la Arqueología Española y hasta cierto punto de la Arqueología Clásica de la parte occidental del Imperio.

En lo que respecta al acceso a la finca, los espacios permanecen inalterados. Tras recorrer el mismo camino, y flanquear la misma torre de interés decorativo que recibe al visitante, se accedería al patio. Esta zona sigue sirviendo para el acceso de personas y vehículos, y en todo caso para recibir el combustible que haría funcionar las termas, a cuya zona de servicio, ubicada como es frecuente en la parte meridional del edificio, se accede directamente desde aquí, y para el trabajo de la servidumbre encargada del mantenimiento del hipocaustum y el praefurnium. Permitiría también, aunque esta vez desde la zona norte, que los usuarios accediesen al interior del edificio a partir de un pequeño pórtico.

El edificio como tal se ordena en torno a un patio central cubierto, que a la vez sirve como frigidarium del espacio termal. Alrededor de él se organizan las diferentes estancias. Sus dos ejes definen un cambio de orientación con respecto a la fase anterior de $10^{\circ}$, aunque en determinados puntos se conserva la orientación anterior a causa de la necesidad de reaprovechar determinados elementos constructivos preexistentes, sobre todo la fila de tabernae que se abren en la fachada. Está además reexcavado con respecto a la cota de suelo que estaba en uso en la fase II, situándose los nuevos solados a $60 \mathrm{~cm}$ por debajo de aquella.

En su interior y a su alrededor se definen cinco bloques funcionales: la fachada norte y las tabernae; el patio central y el sector termal; el pequeño pórtico del cuerpo noroeste; el cuerpo nordeste; el jardín orientalizante.

\section{La fachada norte}

La fachada norte se resuelve mediante la reconversión de las habitaciones preexistentes de la fase II. Una de ellas ocupa la mitad oriental de la fachada, constituyendo una terraza sobreelevada $60 \mathrm{~cm}$ con respecto al resto del complejo. La mitad occidental de la fachada cuenta a su vez con dos ambientes, de hecho dos tabernae. Estos espacios estarían ornamentados de algún modo, pues sabemos del recurso a los pilares de planta hexagonal que debían ofrecer una columnata al exterior, una especie de pórtico que dotaría de cierto aspecto canónico (en lo que a la arquitectura romana se refiere) a este el principal acceso a la edificación.

Inmediatamente al norte del frigidarium se levantaba una habitación rectangular de orientación Norte Sur y dimensiones de 3'50 x 7 m (figs. 13 y 14). El muro es de opus caementicium, conservándose solo a nivel de zócalos. Las esquinas se refuerzan por medio de sillares, y el acceso se realiza desde los dos lados largos: por el Este, desde el pasillo, donde encontramos también un sistema constructivo a base de tubos de arcilla cocida (tubi fictile) con cuello abocinado y forma cilíndrica. Este diseño permitiría embutir estos elementos en diversas posiciones y unirlos con mortero, con lo que se crearía un sistema abovedado de cubierta, empleado en la albañilería de calidad, sobre todo para luces no demasiado amplias.

\section{El patio central y el sector termal}

El patio central y el sector termal constituyen la parte más importante del edificio, la que acoge un programa iconográfico más elaborado, la que, junto al jardín, presenta un mayor número de elementos de alto 


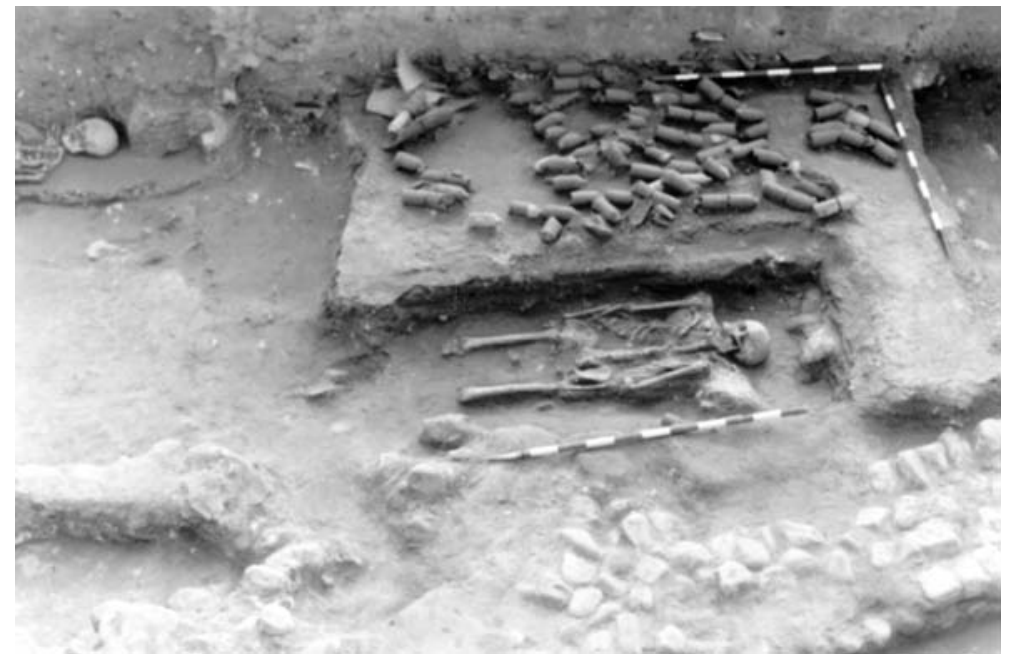

Figura 13. Detalle de la excavación del pórtico al Noroeste, mostrando el derrumbe de tubi fictile. Imagen Servicio de Arqueología A.H.

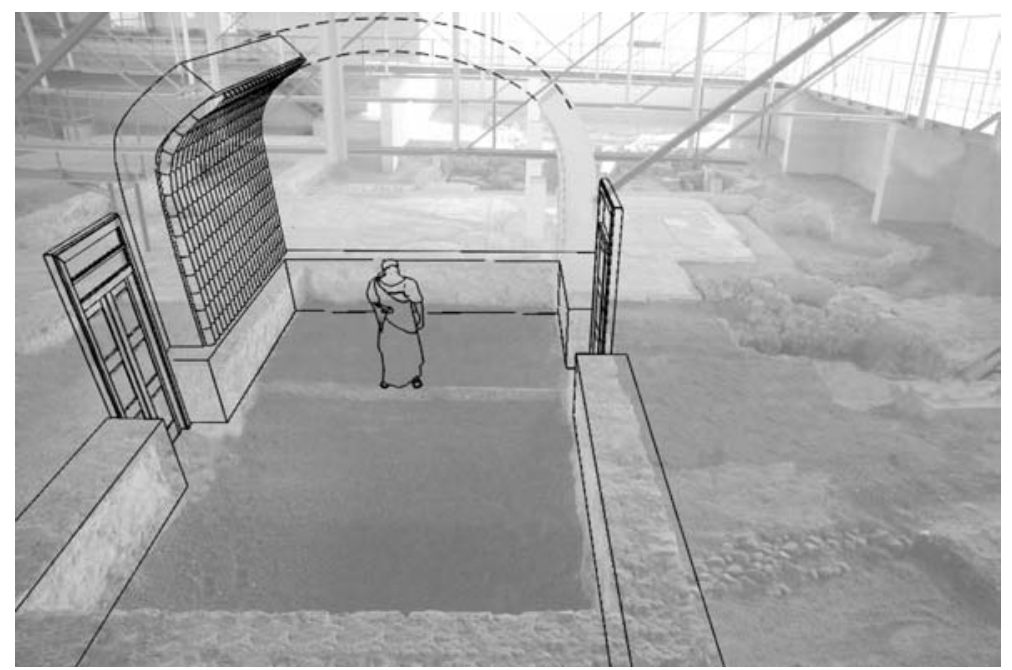

Figura 14. Reconstrucción hipotética de la sala abovedada al norte del edificio, desarrollo sobre los restos conservados. Imagen Servicio de Arqueología A.H. sobre hipótesis de S. Rascón.

coste económico. Un pasillo se abre desde la fachada norte, permitiendo el acceso desde el exterior, según el mecanismo habitual de entrada a la casa romana, unas estrechas fauces que desembocan en un patio interior (lo que en las viejas casas itálicas tradicionales desembocaba en un atrium). El pasillo, de 2'10 m y una longitud de 11'30 m, nace en unas escaleras de dos peldaños de ladrillo y revestimiento de opus signinum, que salvan el desnivel de $60 \mathrm{~cm}$ ocasionado entre el exterior del edificio y el suelo de uso interior. Al final de las fauces se accede al gran patio central, que no es otra cosa que el acceso a las salas termales.
El patio central (figs. 15 y 16) y sus flancos este y oeste, sendas piscinas, de hecho constituyen el frigidarium de las termas. Sus dimensiones son de 7'50 x 10 $\mathrm{m}$, y se subdividiría en dos partes: el patio propiamente dicho (un patio cubierto), en torno al cual se organizan una serie de estancias, y un pórtico separado por tres pilares del espacio principal.

En el patio se halló el mosaico principal de la Casa, compuesto por una serie de escenas geométricas que rodean y enmarcan un emblema con una escena de pesca de tradición iconográfica norteafricana y con inscripción. La banda occidental del patio presenta sin 


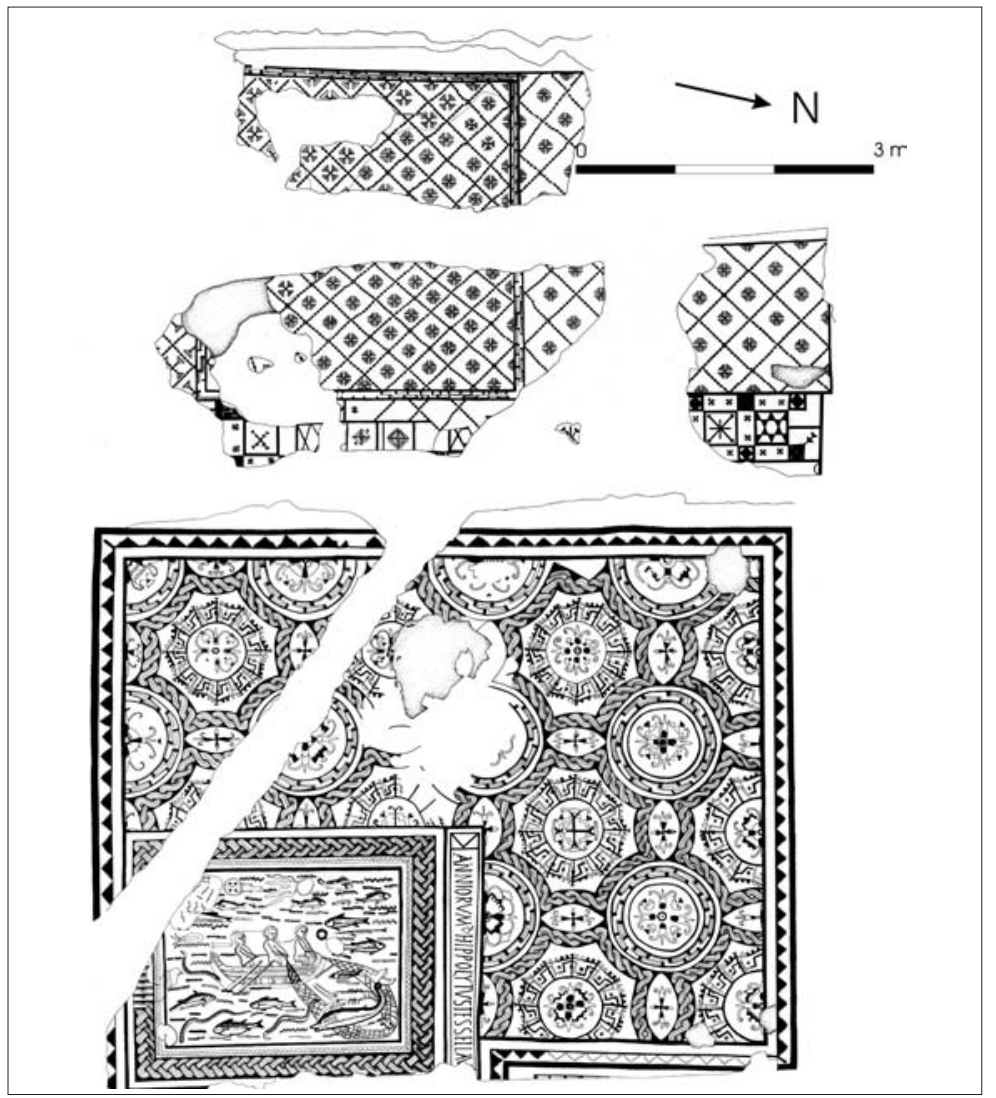

Figura 15. Planta de la sala central del edificio, con sus dos salas decoradas con mosaico. Imagen Servicio de Arqueología A.H.

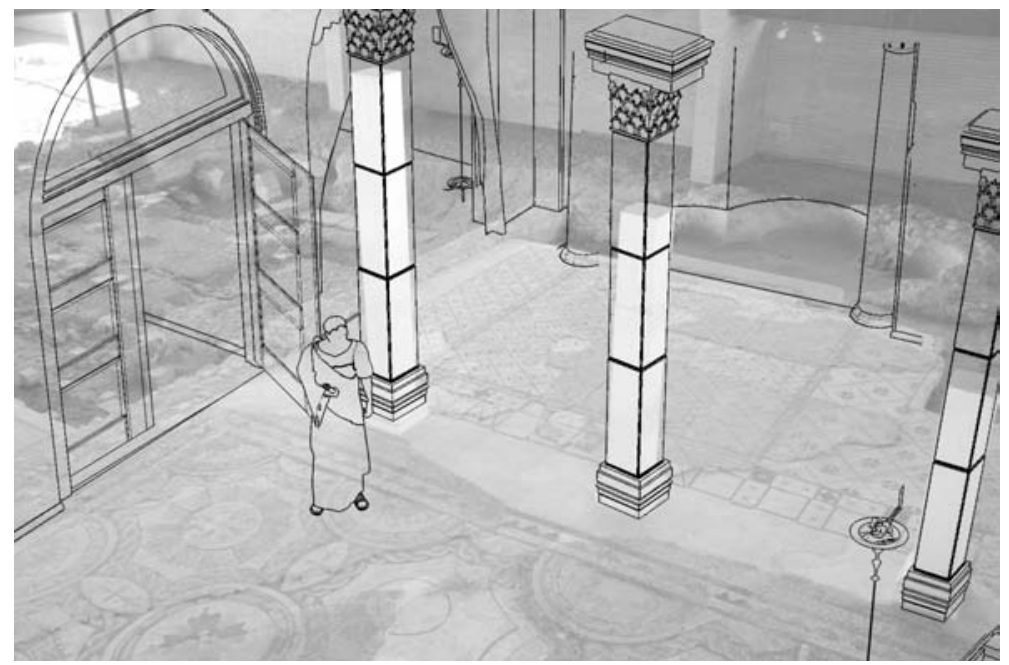

Figura 16. Reconstrucción hipotética de la sala central / frigidarium, vista desde el Este. Imagen Servicio de Arqueología de A.H. sobre hipótesis de S. Rascón. 


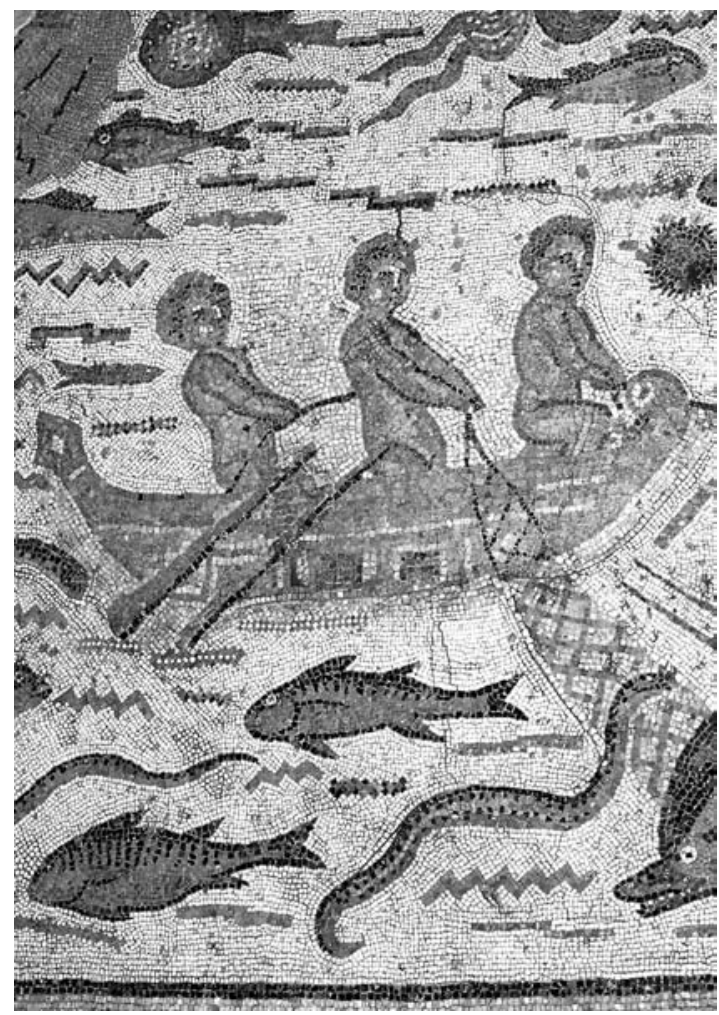

Figura 17. Emblema con escena de pesca que representa la fauna marina del Mediterráneo. Imagen Servicio de Arqueología de A.H.

embargo una pavimentación diferente, también en opus tessellatum, pero de un diseño distinto. Los dos mosaicos están separados por una zanja de expolio, que ha sustraído las columnas o pilares que articularían el paso entre los dos suelos, y que definirían en el lado oeste un espacio porticado y cubierto de 7'50 x 3'80 m. Conservamos en todo caso una serie de fragmentos de lastras de capiteles de piedra de yeso con decoración de hojas de acanto ${ }^{17}$ que nos remiten a una breve columnata de orden corintio.

Pero también en el patio se desarrolla uno de los elementos arqueológicos más importantes del edificio, un juego iconográfico que pretende trasladar visualmente

17 Rascón, 1998. Hemos constatado que en alguna publicación estas piezas aparecen erróneamente interpretadas como estucos (concretamente, García-Entero, 2004, 145; en esta interpretación se cita nuestro trabajo de 1998, donde en ningún momento se identifican con estucos estas decoraciones). Un análisis visual revela que se han tallado sobre piedra de yeso, material por otro lado de uso frecuente en Complutum, tanto por la abundancia de canteras como por las facilidades técnicas que ofrece a los canteros. al espectador al mundo del Mediterráneo. La piscina de planta cuadrada y de agua fría, el emblema del mosaico principal, y la piscina trilobulada forman una alineación para este juego de primitivos trampantojos resueltos mediante pintura mural y mosaicos.

El emblema que preside el mosaico principal, que ya ha sido objeto de un estudio específico ${ }^{18}$, se encuentra descentrado en relación con el resto del pavimento del patio cubierto y sala principal de la Casa. El mosaico desarrolla un campo geométrico dispuesto en "U" alrededor de su emblema, contraviniendo la norma habitual de la musivaria romana. La composición emplea un campo de círculos y octógonos curvilíneos. El emblema (fig. 17) está producido por un grupo de artesanos diferente del que realiza el campo geométrico, tal y como se evidencia en la diferente confección, tamaño de teselas, materiales empleados, e incluso cama de preparación. Consta de tres partes: inscripción, marco y cuadro. La inscripción se encuentra en el lado norte del emblema. Se puede leer el texto, enmarcado por dos triángulos rojos (aunque sólo se conserva el de la izquierda), imitando una tabula ansata.

\section{ANNIORUM (hédera) HIPPOLYTUS TESSELAV [IT]}

Como ya hemos mencionado, el texto tiene dos lecturas: la primera la desarrolla Gómez Pallarés en el trabajo ya referido ${ }^{19}$ :

\section{Hippolytus [que pertenece a la familia] de los Anios lo teseló.}

Donde se hacía depender a Hipólito del genitivo Anniorum, siendo áquel el legítimo autor del mosaico (sólo del emblema, y éste es un aspecto de la lectura que no ofrece dudas), y a la vez esclavo, liberto o dependiente en algún modo de la familia de los Anios. Y sin embargo existe otra lectura posible:

[Casa ] de los Anios. Hippolytus teseló [este mosaico]

A nuestro juicio más acorde con las relaciones laborales en la Antigüedad romana, que difícilmente elevan a estos rangos a los artesanos, amén de que el propio Gómez Pallarés ${ }^{20}$ corrige su lectura anterior, partiendo también de criterios epigráficos. Además, esta nueva lectura encaja con los hábitos epigráficos de las sedes colegiales, que recogen documentos como el álbum de

\footnotetext{
${ }^{18}$ Existe un trabajo monográfico sobre este mosaico en Rascón, Polo, Gómez Pallarés y Méndez, 1998.

${ }^{19}$ Nuevamente, Rascón, Polo, Gómez Pallarés y Méndez, 1998, 55 y ss.

${ }^{20}$ Gómez Pallarés, 2001, 220.
} 
la corporación, su normativa básica y, sobre todo, el reconocimiento hacia el patrono, que financia la mayor parte de los gastos, sobre todo de la construcción de las sedes. Como también sabemos que los Anios son una importante familia complutense, documentada en la epigrafía mayor del mausoleo que formaba parte del mismo complejo arquitectónico que este mosaico, lo más adecuado es suponer que el texto anniorum es la firma de los propietarios y patronos de esta sede, y en general de todo el complejo.

En todo caso el cuadro del emblema propiamente dicho representa una escena de pesca en la que tres erotes navegan en una barca. Están rodeados de fauna marina: entre otros, dorada, pulpo, calamar, pez espada, murena, langosta, gamba, sepia, delfín y erizo de mar. Tal y como hemos indicado en trabajos específicos ${ }^{21}$ se trata de una obra que alude inmediatamente a las producciones norteafricanas, tanto por la temática como por el material pétreo empleado. Nos interesa aquí resaltar, además, el carácter didáctico que muchos autores han reconocido ya a este tipo de obras ${ }^{22}$, que actúan como catálogos de la fauna marina mediterránea. Los erotes, resueltos con cierta tosquedad, son un acompañamiento para el verdadero trabajo del pictor imaginarius, que no ahorra esfuerzos para representar detalladamente a cada una de las especies mencionadas. El emblema tiene por tanto un interés enciclopédico: cataloga la fauna, con objetivos semejantes a los de varias obras literarias de la época.

Al margen de otros mosaicos, de inferior interés artístico e histórico y en los que no vamos a detenernos, se han recuperado en la Casa de Hippolytus otros materiales que procede mencionar: en primer lugar la pintura mural. El conjunto de pinturas que procede de la piscina de agua fría, a pesar de su mal estado de conservación, se han podido interpretar por parte de la Profesora Guiral ${ }^{23}$ como una producción del siglo III o IV, coincidente por tanto con el mosaico de Hippolytus, y que representaría una escena común en los repertorios norteafricanos: el triunfo de Venus. Esta piscina de agua fría se halla pavimentada con otro mosaico, más sencillo en su composición y ejecución, pero de indudable interés arqueológico. Se resuelve con un fondo de tonalidad crema sobre el que se disponen sin orden aparente teselas de colores más oscuros -principalmente, negras- buscando acentuar con este efecto el movimiento de las aguas. Las paredes de la estancia, que alcanzan en la actualidad 1,20 m de altura, están profusa-

\footnotetext{
${ }^{21}$ Rascón, Polo, Gómez Pallarés y Méndez, 1998, 50 y ss.

22 Así Balil, 1960, 284 y 292, y Bobadilla, 1969, que juegan con el término "manual de ictiología", es decir, un conocimiento enciclopédico, y lo combinan con la sabiduría culinaria.

${ }^{23}$ Guiral, en prensa.
}

mente decoradas con las referidas pinturas murales. Los muros de la piscina tienen un grosor de $90 \mathrm{~cm}$ en el caso del muro este y $75 \mathrm{~cm}$ en el caso del norte y el sur, habiendo sido expoliado por completo el oeste. El sur se encuentra también en muy mal estado de conservación, dado que ha sufrido un expolio parcial en el punto donde se encontraría el desagüe. Están ejecutados con alma de opus caementicium y aparejo exterior que entraría en la categoría de opus mixtum: una primera hilada de ladrillo a ras de suelo, y una segunda hilada a $75 \mathrm{~cm}$ de altura (medidas que no siempre se respetan, lo que unido al desigual estado de conservación del muro motiva que de hecho el ladrillo no pueda divisarse de corrido por todo el muro). Entre ambas, la obra de piedra, un pseudo vittatum que emplea bloques de caliza poco trabajados, de dimensiones que oscilan entre 15 x $10 \mathrm{~cm}$ y 25 x $18 \mathrm{~cm}$, pero que en todo caso seleccionan la mejor de las caras para ofrecer al exterior. Este tipo de obra por otro lado es el que sirve de perímetro al edificio entero por la parte este y parcialmente por la sur.

En lo que respecta al pórtico columnado del lado occidental, permite el acceso a un estanque o piscina de planta trilobulada, visible desde la piscina cuadrada de agua fría. El pavimento del estanque es de opus signinum, al igual que el revestimiento interior de las paredes, que se pintaron de color verde oscuro. La articulación entre suelo y pared se efectúa por medio de un cuarto de bocel. Del alzado tan solo se conservan 0'60 m. y todo parece indicar que estaban revestidos de mosaico. Igualmente se remataría mediante una cúpula de mosaico, aunque el estado de conservación del mismo nos impide conocer otros detalles sobre él aparte de los materiales utilizados, mayoritariamente pasta vítrea. Por último el pórtico se complementa con una pequeña pila con planta octogonal irregular de ejes de 1'15 x 1'10 m, ejecutada en opus caementicium y revestida de opus signinum.

En realidad, esta descripción se resume en un sencillo esquema donde dos piscinas flanquean el patio principal: constituyen la zona dedicada a los baños de agua fría. La primera, por el este, es una piscina rectangular. En el mismo eje, por el oeste, el estanque de planta trilobulada, con pavimento de opus signinum y con una cúpula revestida de mosaico. La decoración es de origen norteafricano, y en conjunto busca representar un gigantesco trampantojo -algo por lo demás habitual en la decoración arquitectónica de los espacios domésticos romanos desde el siglo I d.C.-, de forma que, quien se sumerge en la piscina cuadrada de agua fría, asiste gracias a la pintura mural al triunfo de Venus, sobre su cabeza, quizá porque está en una gruta. Ante él, se abre el Mediterráneo, con un catálogo bastante completo de especies. Al fondo, otra gruta (la piscina trilobulada), que decora paredes y cúpula con un mosaico también de 
decoración naturalista (quizá, incluso, enmarcaría alguna escena que no se ha conservado).

Respecto a las salas calefactadas, se conserva un hipocausto que delata dos naves de dirección norte - sur, resueltas por medio de sendas bóvedas ${ }^{24}$. Ambas tienen calefacción directa, cada una de ellas alimentadas desde un praefurnium que se ubica al sur. La sala oriental (de hecho un caldarium, más que un tepidarium) carece de piscina, a diferencia de la occidental, y tiene unas dimensiones de 3'50 × $7 \mathrm{~m}$. Esta sala oriental estaría partida en dos, pues se conservan restos del muro de sillares y ladrillo que la cortaría transversalmente, y define dos salas, una en la mitad meridional, otra en la septentrional, cuyos usos no vamos a entrar a discutir aquí, porque no es el objeto de este trabajo. La occidental, con una piscina (concretamente un alveum) que ocupa un ábside que la remata por el lado oeste, mide 4'50 x 7 m y la documentación arqueológica es explícita a la hora de considerar que sólo existe un ambiente, una única sala que es un caldarium con alveum. Ambas contaban con suelo de mosaico de decoración desconocida, aunque sabemos que al menos se embellecería con un tema marítimo. Sólo se han recuperado algunos fragmentos.

Hacia el sur la infraestructura de la sala se prolonga mediante dos praefurnia, con sendas bóvedas de medio punto truncadas y separados por un machón de adobe y ladrillo, con bloques de piedra de yeso en sus respectivas bocas. Se alimentaban desde un recinto de planta cuadrangular de 5'60 x 6'80 m para uso de los sirvientes encargados del funcionamiento del complejo termal. Dentro del mismo existe un pequeño horno, de planta ovalada, con unas dimensiones de 2’30 x 1'30 m. Las paredes, de las que se conserva tan solo el apunte del alzado, son de tapial y se resolverían con una bóveda o falsa bóveda, que se documentó en la excavación arqueológica. El suelo es de ladrillos, empleando el formato de tipo pedalis $(31 \times 31 \mathrm{~cm})$ y complementado con fragmentos diversos. Hay que suponer la existencia de una parrilla metálica o incluso de adobe que no se ha conservado y que serviría para depositar los alimentos que se querían someter a altas temperaturas. Ya que no hay indicios de producción industrial, sólo se nos ocurren dos funciones para este horno: una, la de calentar piedras que aporten un calor seco a alguna de las estancias calientes. Otra, la más probable, cocinar alimentos.

\footnotetext{
${ }^{24}$ Hemos de hacer constar que en alguna publicación reciente (en concreto García Entero, 2004, 145 y ss., sobre todo figura 3) las salas calientes de las termas están mal publicadas, empleándose un plano incorrecto y por tanto una distribución funcional igualmente equivocada, que se contradice con los datos arqueológicos reales, que la autora no ha consultado. Lo criticamos en detalle en un addendum a este nuestro artículo, y ofrecemos el plano correcto.
}

Esta hipótesis es congruente con la documentación arqueológica, porque el análisis de la fauna del yacimiento indica una gran abundancia de animales jóvenes, a los que por tanto se ha debido sacrificar para su consumo. La fauna es muy abundante, se recuperó en su mayoría en el vertedero que existió a lo largo de los siglos I y II junto el acceso al recinto del edificio, y no hay alrededor ningún otro edificio del que puedan proceder los vertidos. Por tanto, es basura procedente de las actividades humanas en la propia Casa de Hippolytus. El banquete como acto social, por cierto, debió ser una de las actividades corporativas más frecuentes en este edificio (vid infra).

También al sur del frigidarium y por su parte oriental encontramos una salida al exterior. Se resuelve mediante un solado de opus signinum de $3 \times 3,50 \mathrm{~m}$ donde se abre un pozo que baja hasta el nivel freático. El pozo se ha excavado hasta una profundidad de $2 \mathrm{~m}$ y no se ha encontrado ninguna preparación para las paredes, ya que el brocal original, probablemente de piedra, ha sido expoliado. Los análisis de aguas que se han efectuado han podido documentar en las mismas unas cualidades minero-medicinales que se refieren sobre todo a sus altos índices de sulfatación, lo que las diferencia del resto de las aguas del entorno. Esta calidad de las aguas está probablemente ligada con la existencia del edificio, y el aprecio que de ellas se hace está patente en el respeto por la estructura, que queda aislada sin ningún otro uso específico que ese: permitir el acceso de los usuarios del complejo termal al pozo.

Esta salida al exterior permitía el acceso a las letrinas (figs. 18 y 19), que se alineaban al sur de la piscina de agua fría. Sus dimensiones son de 7'50 x 2'70 m, y conservan un pavimento de opus tessellatum muy deteriorado, con diversas lagunas, algunas de las cuales tienen una restauración de signinum de época romana. El mosaico ocupa lógicamente tan solo el interior de la habitación, pues la banda perimetral, que coincidiría con los asientos para los usuarios y la evacuación de aguas ha desaparecido.

El muro que define las letrinas es prolongación del ya descrito en la piscina de agua fría, si bien solo conserva su alzado parcialmente por el lado este, el que daría al exterior, donde muestra de nuevo el aparejo de pseudo vittatum, siendo tan solo observable en el resto de su recorrido el opus caementicium que sirve de base. La anchura del muro es también algo menor que en el caso de la piscina, siendo en las letrinas de $60 \mathrm{~cm}$.

\section{El pórtico del ala noroeste}

Con respecto al ala noroeste, definimos como tal a efectos descriptivos el conjunto de habitaciones delimitadas por el frigidarium por el sur, el pasillo o fauces por el este y el conjunto de habitaciones que componen la 

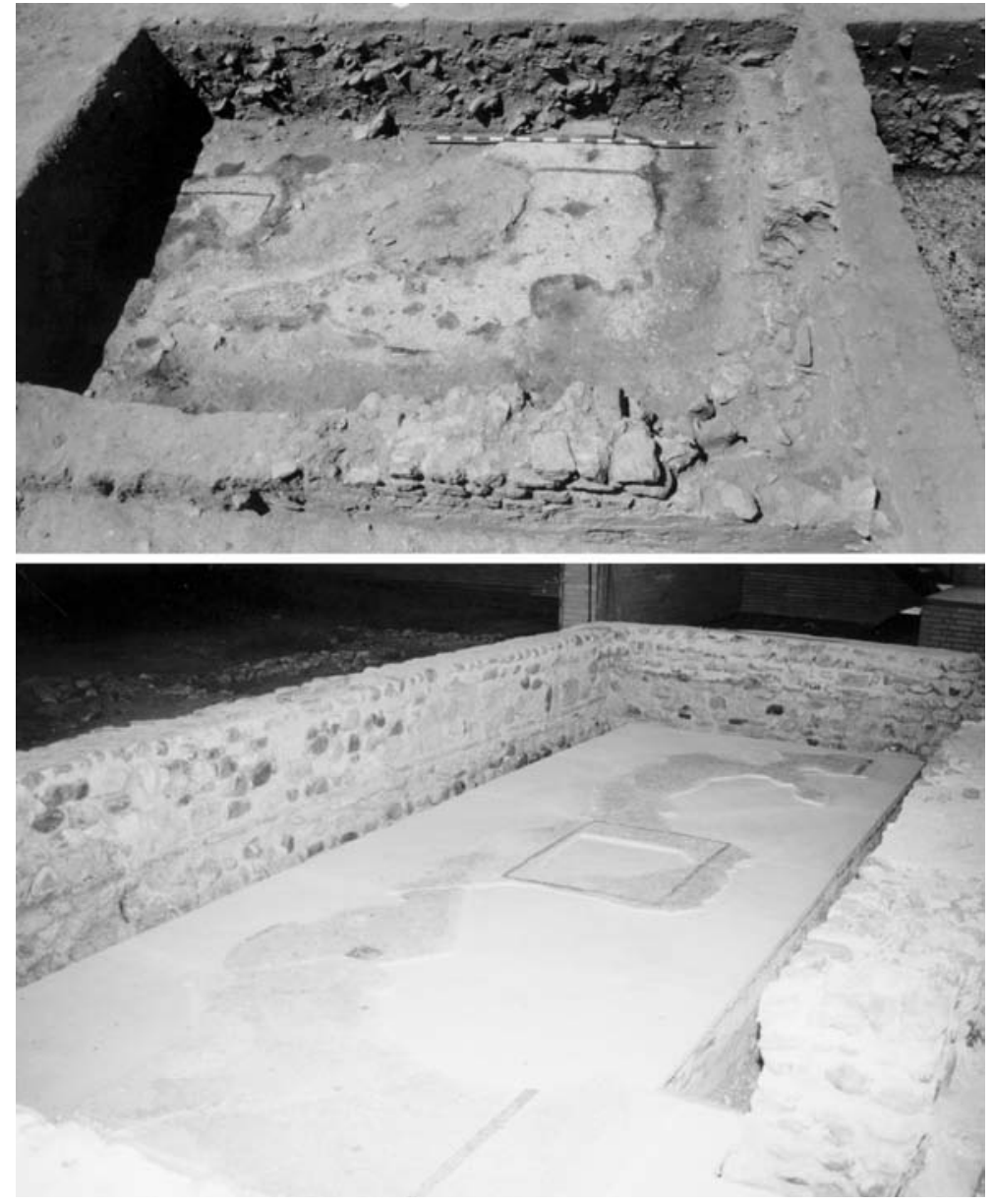

Figura 18. Las letrinas, durante el proceso de excavación y restauración. Imagen Servicio de Arqueología de A.H.

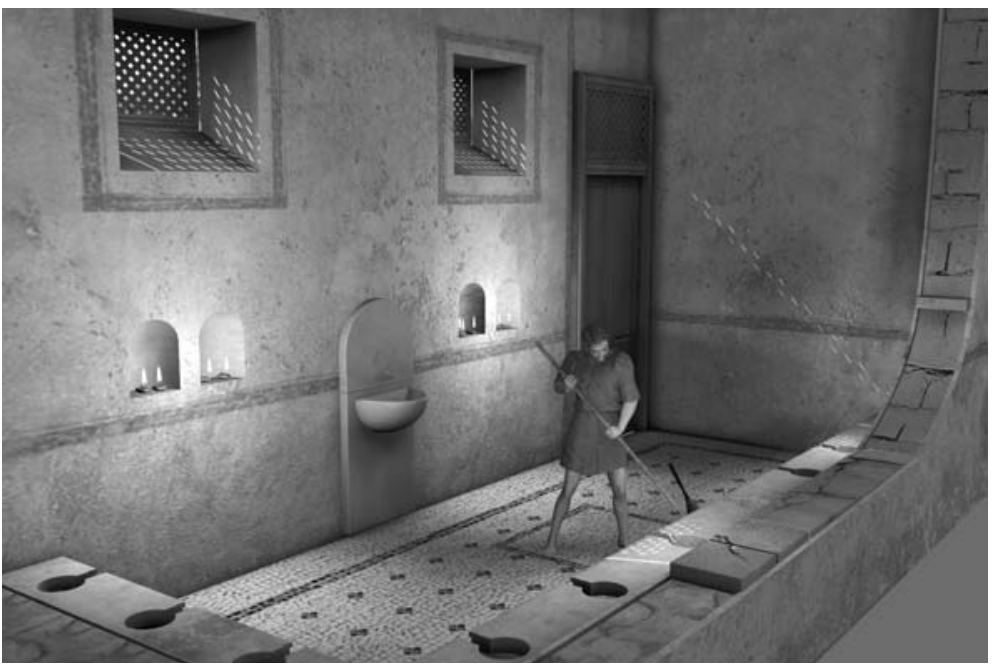

Figura 19. Las letrinas. Hipótesis de levantamiento tridimensional. Imagen Servicio de Arqueología de A.H. sobre hipótesis de S. Rascón. 


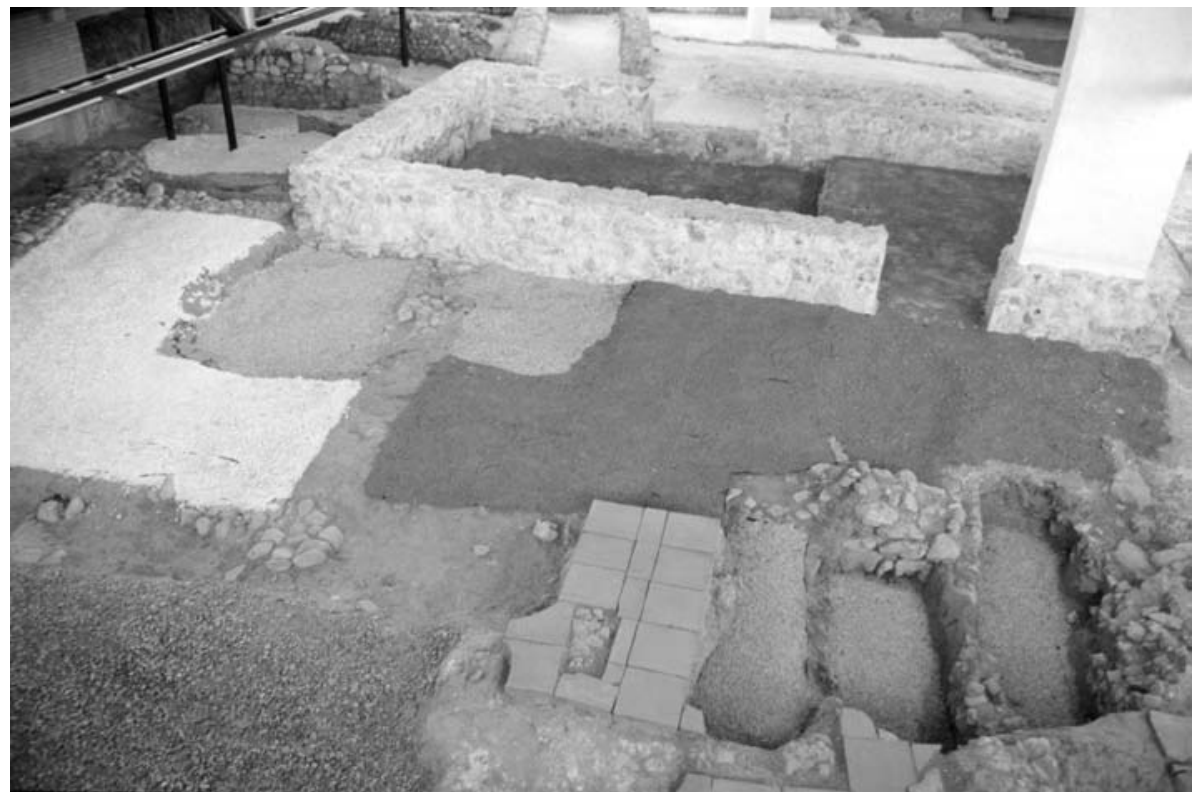

Figura 20. Vista general del pórtico ubicado al Noroeste, tal y como se acondicionó para su musealización. Imagen Servicio de Arqueología de A.H.

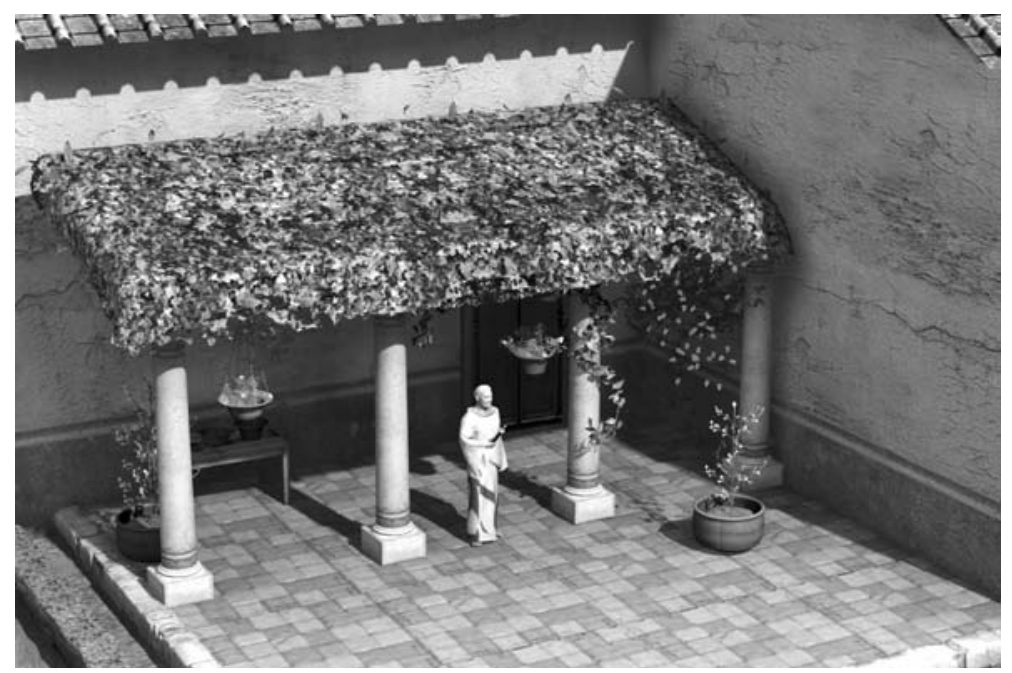

Figura 21. Hipótesis de reconstrucción tridimensional del pórtico ubicado al Noroeste y los elementos que lo ornamentarían, en función de los datos arqueológicos y arqueobotánicos. Imagen Servicio de Arqueología de A.H. sobre hipótesis de S. Rascón.

fachada septentrional por el norte. Al oeste de la sala de tubi fictile ya descrita, se abre un recinto de planta trapezoidal, que sería en realidad una especie de pórtico (figs. 20 y 21), que por otra parte debe suplir a algún elemento semejante de la fase II, y que enlazaría el exterior con esta sala abovedada. Está concebido con dos alturas escalonadas, separadas por un peldaño de opus caementicium muy basto, probablemente rematado con baldosa cerámica o con mármol que no se encuentran in situ, aunque tales materiales constructivos están presentes en el repertorio de materiales muebles recuperados por la excavación arqueológica. Esta solución de dos niveles separados por un escalón es la misma que se aprecia, como veremos, en el jardín de la fachada oriental. Además, contaba con un pequeño pórtico pegado a la fachada propiamente dicha. Un zócalo de muro de bloques de piedra caliza sin labrar separaba este pórtico del resto de la terraza. En total la terraza tenía unas dimensiones 


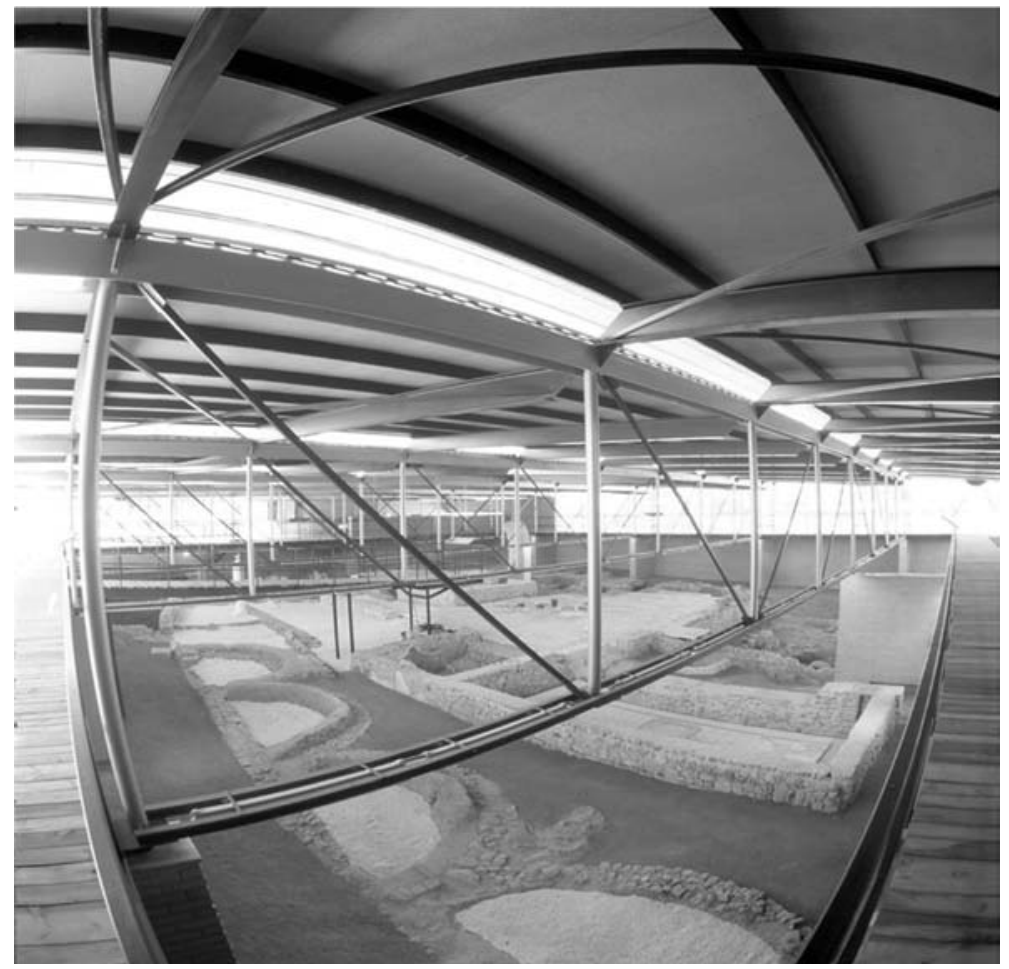

Figura 22. Vista general de la línea de exedras que define el jardín por su lado occidental. Imagen José Latova.

aproximadas de $49 \mathrm{~m}^{2}, 40 \mathrm{~m}^{2}$ en la parte alta y $9 \mathrm{~m}^{2}$ en la baja. El pórtico tiene $8 \mathrm{~m}$ de frente y un fondo de $3 \mathrm{~m}$, con lo que desarrolla una superficie de $24 \mathrm{~m}^{2}$.

El pórtico está pavimentado con opus signinum. Mientras, las dos terrazas que se abren ante él cuentan con un suelo de baldosas cerámicas, con un formato de 1 pie por 1 pie $(29$ x $29 \mathrm{~cm})$. Sólo se han recuperado algunas baldosas pues la terraza ha sufrido el expolio de sus materiales constructivos y, además, en la fase IV terraza y pórtico han sido elegidos para soportar hasta seis sepulturas de inhumación, lo que empeora su estado de conservación. En la musealización del edificio se optó por reintegrar parcialmente las baldosas que habían desaparecido.

Por otra parte, en la terraza se han apreciado restos de al menos una olla enterrada que ofrece su boca a aproximadamente la cota del suelo de uso. Resulta evidente, por tanto, que en ocasiones las baldosas se suplían por contenedores cerámicos, muy probablemente concebidos como macetas: asociadas con este contenedor y las baldosas de barro cocido se recuperaron semillas, cuyo análisis ha demostrado que se trata de hipérico y de cariofiláceas (se trataría de plantas de flor, ornamentales, emparentados y semejantes a los claveles y clavelinas que, en fechas más modernas, se han desarrollado y popularizado en España y otros paí- ses europeos con uso ornamental): plantas de flor, curativas o medicinales, pero también al menos la cariofiláceas, de uso ornamental, de tipo arbustivo, aptas para ser dispuestas en macetas ${ }^{25}$. Se ha relacionado estos restos con otras cerámicas halladas en la excavación, grandes contenedores para los que se propuso la identificación como macetas.

\section{El ala nordeste}

Respecto al ala nordeste, ubicada entre el pasillo de acceso, la fachada norte y la piscina de agua fría, encontramos primeramente un recinto de 5'90 x 2'90 m. Este recinto, probablemente un pequeño hortus, constituiría la entrada a un nuevo ambiente que a su vez articula un paso directo a la zona exterior.

En esta zona hemos de destacar la presencia de una amplia estancia con muros de opus caementicium y alzado desconocido, quizá de sillarejo, de planta trape-

\footnotetext{
${ }^{25}$ Para el estudio que sigue, el análisis de estructuras y semillas a cargo del proyecto Arqueología de los Jardines Romanos en España, financiado por la Fundación Dumbarton: A.L. Sánchez Montes, S. Rascón, J. Burjarch, J.J. Tresserras, y J. C. Matamala. Análisis arqueobotánico, resumido en Tresserras, Matamala y Burjachs, 2002.
} 


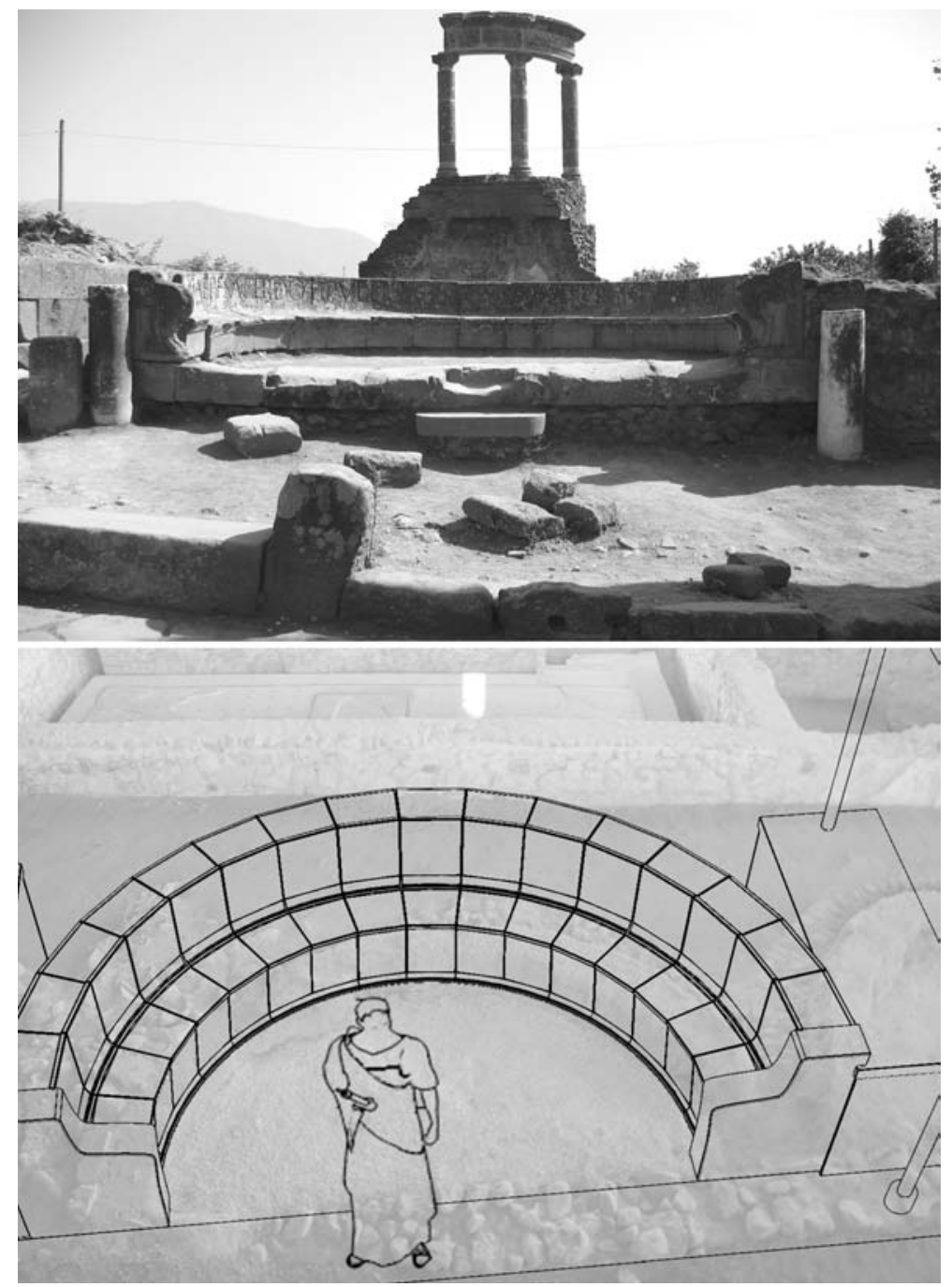

Figura 23. Arriba, una de las exedras dedicadas a la conmemoración funeraria en Pompeya, concretamente una de las dos de la Vía de los Sepulcros, a la salida de la Puerta de Herculano. Imagen Ana Lucía Sánchez. Abajo, hipótesis de reconstrucción tridimensional de una de las exedras del jardín de la casa de Hippolytus. Imagen Servicio de Arqueología de A.H.

zoidal forzada por la adaptación a los dos ejes que rigen la planimetría del edificio. En su interior esta sala estaría decorada con mosaicos parietales, que se han podido documentar entre el derrumbe de la misma. Teniendo en cuenta que sólo se conservan algunos fragmentos de diverso tamaño y colorido, sabemos que se trata de composiciones vegetales resueltas mayoritariamente en pasta vítrea. Con respecto al pavimento conservamos solo el suelo de tierra, aunque existe evidencia arqueológica de que se ha retirado un pavimento en esta sala y la que se desarrolla al sur durante la fase IV.

Se ha recuperado sin embargo un elemento muy importante para la comprensión de esta sala: una estatua de Diana, desgraciadamente mutilada de forma tal que solo se conserva la mitad inferior. Como elemento escultórico complementario, ha aparecido una basa de columna de caliza, si bien desplazada de lo que sería su posición inicial. Todo ello nos ha llevado a pensar en un sacellum para el culto, donde se veneraría a la diosa que se dispondría probablemente en algún nicho o arco emplazado en el desaparecido muro oeste.

\section{El jardín}

Finalmente, en el Este encontramos una zona exterior que se resuelve mediante un jardín (figs. 22, 23 y 24). Se extendería, en su zona mejor documentada, a lo largo de todo el lateral oriental (un total de $30 \mathrm{~m}$ ), 


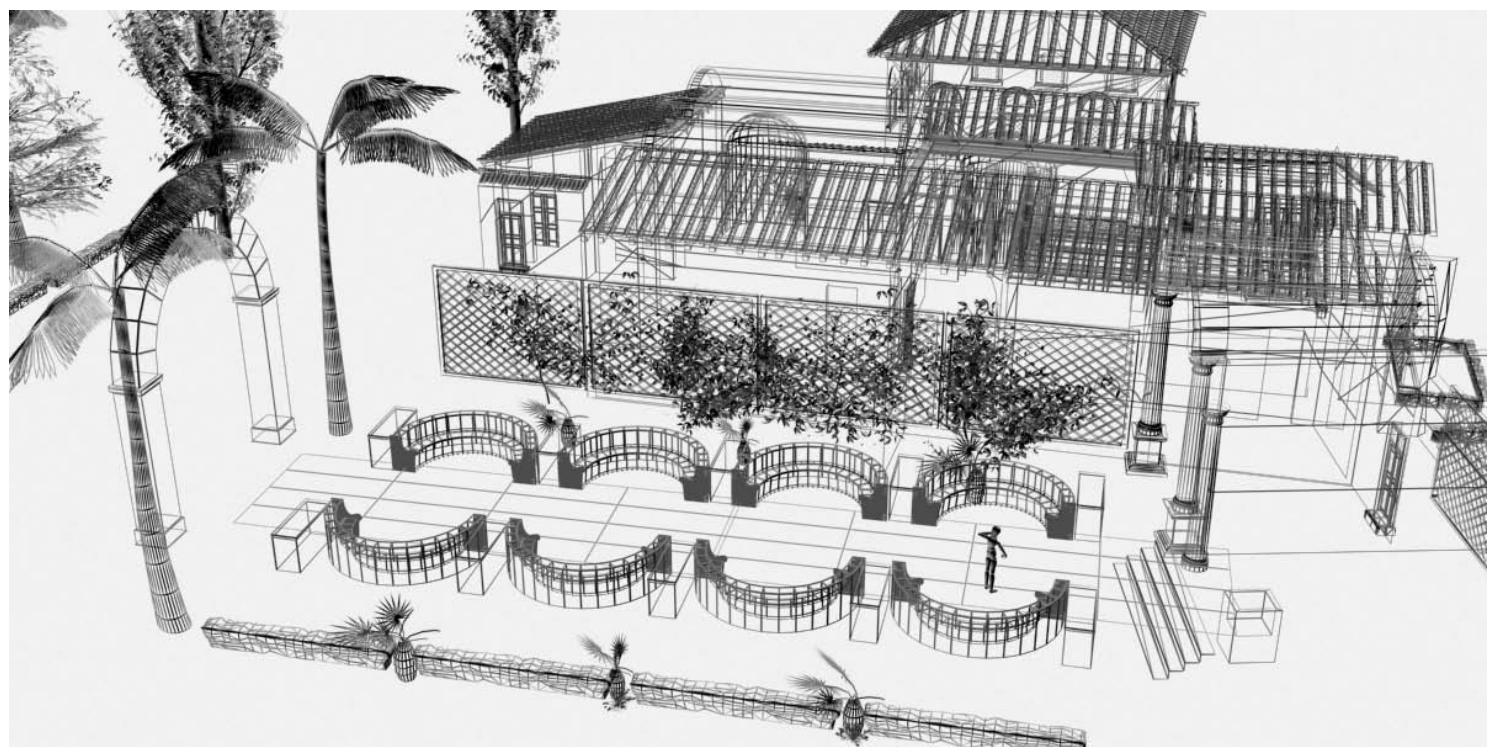

Figura 24. Hipótesis de reconstrucción tridimensional del jardín de los Anios, con la ubicación más probable de algunas de las especies documentados por el estudio arqueobotánico. Imagen Servicio de Arqueología de A.H. sobre hipótesis de S. Rascón y A.L. Sánchez.

estructurado en dos partes, cada una de las cuales ocupa una terraza, y conectándose ambas por medio de una escalera: la parte Norte es un espacio diáfano, de $8 \mathrm{~m}$ de longitud. En la sur se configura un pasillo flanqueado por dos filas de exedras, y con una longitud de $28 \mathrm{~m}$. Al Norte se desarrollaría un jardín con especies documentadas en el análisis de restos pero de las que desconocemos la distribución en planta.

A la segunda se accede por medio de las referidas escaleras. A sus pies surge un pasillo de opus signinum, enmarcado por dos elementos arquitectónicos. A la derecha, un sillar que serviría de plinto a un elemento exento (una columna, una escultura o una crátera). A la izquierda, un pequeño estanque. A continuación, a cada lado del pasillo se extiende una fila de cuatro exedras, cada una de las cuales se configura como un banco corrido. Los bancos, realizados alternando el tapial y el canto rodado, tenían un revestimiento que combinaba la pintura con el ladrillo, éste ubicado en la parte destinada a asiento. El ladrillo ha sido expoliado, pero se conserva una impronta que delata el uso de piezas de $30 \mathrm{~cm}$ de longitud y una anchura variable, lo que sugiere que se utilizaron ladrillos o quizá más bien fragmentos de mármol de tipo pedalis cortados longitudinalmente para lograr la curvatura necesaria. Unos pequeños tabiques separaban cada exedra de la siguiente, y probablemente constituían a la vez el soporte para algún tipo de parasol: celosías que se cubrirían de vegetación.

A esto se añadiría una amplia superficie, al Sur y al Este, por donde el jardín se extendería con plantas que exigen un gran desarrollo volumétrico. Concretamente, la existencia de ciertas especies (por ejemplo, el cedro) reclama un desarrollo amplio, hacia el arroyo Camarmilla, donde contactaría con el mausoleo de la familia de los Anios, que serviría de cierre al jardín.

Las evidencias para clasificarlo como un jardín son varias: primero, en este espacio se ha realizado un análisis de polen, y sobre todo de microrrestos, entre los que destaca la recogida de fitolitos. El resultado es que hay una gran cantidad de especies que se documentan en este limitado recinto: algunas autóctonas, como los pinos, robles y efedras. Otras exóticas, palmeras, cedros, tilos, jazmines, hipérico y cariofiláceas. Es evidente el esfuerzo por contar en este punto con una suma de plantas diversas, procedentes algunas de entornos ambientales muy diversos y distintos de los meseteños (como el jazmín, la palmera y el hipérico) que sólo se conciben en relación con un jardín.

Segundo, se trata de un espacio exterior. El edificio como tal termina en el gran muro que cierra el ala oriental, revocado por el exterior con color rojo.

Tercero, además de las plantas hay otros elementos que obligan a pensar en un jardín: así, los juegos de agua, representados en la fuente o pileta revestida de signinum que se ubica al norte de las exedras. También las aves, como un pelícano y palomas, documentados a partir de los restos óseos. Como bien es sabido, se considera a ambos factores representativos de la jardinería de la época ${ }^{26}$.

\footnotetext{
${ }^{26}$ Así, Grimal, 1990,286 y ss. y 295 y ss.
} 
Cuarto, aquí se imita una ambulatio: Grimal ${ }^{27}$, en su obra sobre jardinería romana, recoge esta categoría, que se encuentra bastante bien documentada. Vitrubio ${ }^{28}$ describe este tipo de paseos, que también se mencionan en la obra de Marcial ${ }^{29}$ y de Plinio el Viejo, y que son en definitiva un jardín lineal, desarrollado en torno a un camino, y que sirven para pasear a pié o en carroza. Este jardín requiere un pórtico o un elemento de cierre semejante, a uno o a ambos lados del paseo, función que en este caso desempeñan las dos filas de exedras. Las exedras representan un tipo de fachada escénica, que se documenta principalmente a partir de la iconografía, y que el mismo Grimal reconoce en varias pinturas de Pompeya y de Herculano ${ }^{30}$.

Quinto, por su desarrollo en superficie, sus especies vegetales y faunísticas, y sus connotaciones ideológicas (el mundo meridional y orientalizante) que coinciden con la iconografía del interior de la Casa, es un jardín excepcional, hasta tal punto que rivaliza en importancia y coste económico con el edificio. Hasta cierto punto, es el edificio el que complementa al jardín, y no al revés, o ambos se complementan el uno al otro.

No es este el lugar para estudiar con detalle nuestro jardín, cosa que se ha hecho en otros foros ${ }^{31}$. Nos interesa sin embargo resaltar tres aspectos: primero, su carácter culto, refinado y orientalizante. Segundo, la relación paisajística del jardín con el mausoleo de los Anios. Tercero, su arquitectura, concretamente el desarrollo de las exedras, que se conciben, como se verá, como espacio de reunión.

La vocación orientalizante del jardín es evidente a partir de las especies que aparecen, tanto animales como vegetales. Desde los datos arqueobotánicos sabemos de la existencia de una serie de árboles: además de pinos, encinas, robles y probablemente olmos, que componen el entorno boscoso, el jardín y sus inmediaciones debieron contar con pino de sombra, olivo (Olea sp.), olmo (Ulmus), tilo (Tilia), cedro (Cedrus) y palmitos (Chamaerops humilis $L$. A esto se unen plantas arbustivas y lianoides. En concreto destaca una considerable presencia del jazmín (Jasminum, 1'9\% de la muestra polínica), pero también de efedras (0’3\%, Ephedra fragilis) y jaras (Cistus, 0'9 \%).

Al margen de especies propias de la Meseta (olmo, pino, olivo y jara), destacaremos la presencia de plantas decorativas y medicinales ya en la época (el tilo) y, sobre todo, especies que sólo se explican a partir de importaciones, quizá en algún caso desde climas merdionales de

\footnotetext{
${ }^{27}$ Grimal, 1990, 255 y ss.

${ }^{28}$ De Arch, 5,9, 2 y ss.

${ }^{29}$ Epig. I, 82.

${ }^{30}$ Grimal, 1990, 267.

${ }^{31}$ Especialmente, Rascón (ed), en prensa.
}

la Península, pero sobre todo desde Próximo Oriente o el Norte de África. El jazmín, además de uno de los mejores representados en la muestra obtenida, es una planta meridional, muy significativa de paisajes de climas cálidos y húmedos, que no soporta los inviernos fríos: es frecuente en la costa sur de España y en todo el litoral norteafricano. Su uso en la jardinería romana, concretamente en Pompeya, está además arqueológicamente documentado, lo que la convierte en una planta "culta" ${ }_{32}$. Siguiendo en la misma línea interpretativa, destaca también la presencia de palmitos y cedros. El primero, y en general la palmera, exige su importación, al menos desde el Sur de la Península, cuando no de África o Próximo Oriente. Caracteriza los paisajes mediterráneos y orientales. También representa naturalezas idealizadas en la pintura y el mosaico: los ejemplos son innumerables.

Más interesante incluso es el cedro. Desaparece de la Península en el Terciario, y es en cambio abundante en el Norte de África, pero sobre todo es uno de los árboles más apreciados de la Antigüedad, especialmente en Oriente Próximo, documentado ya en el Poema de Gilgamesh. Desde el III milenio a.C. es una deseada y perseguida riqueza natural de los bosques del Líbano. Creemos que su presencia en un jardín de la Meseta debe interpretarse como un gesto culto, remembranza de los jardines orientales que, no lo olvidemos, son una referencia universal durante la Antigüedad. La cercanía de palmitos y jazmines no haría sino reforzar esta imagen.

Los datos zoológicos redundan en esa explicación. Las palomas documentadas son probablemente mascotas, pero sin duda lo es el pelícano, un animal que no anida en la Península, siendo sus nidos más cercanos de Mauritania o de la costa entre Libia y el Próximo Oriente, este incluido. Una vez más, el deseo expreso de recrear paisajes de aspecto meridional y oriental, que además se vinculan directamente con el contenido de la decoración del frigidarium y su repertorio de fauna mediterránea, y nos recuerdan que, en paralelo, existía una cultivada devoción hacia la Naturaleza como lugar paradisíaco, al locus amoenus, en la misma literatura romana ${ }^{33}$.

Además, este jardín está ligado directamente con la Casa, pero también con el mausoleo de los Anios. Ya hemos demostrado que éste se encontraría afrontado visualmente con el jardín, de forma que, cuando alguien se sentaba en cualquiera de las exedras, los monumentos funerarios quedaban visibles al Sur, al final de la zona ajardinada, y a una cota levemente superior. Hemos propuesto una reconstrucción virtual del efecto paisajístico que debía conseguirse (fig. 25): las tumbas de la familia

\footnotetext{
32 Jashemskki, 1993.

33 Así entre otros Virgilio, P. Ovidio Nasón, Calpurnio Sículo... En general, ver Bickel, 1982, 603 y ss. Véase también nuestro texto de 1997 en Rascón, 2001.
} 


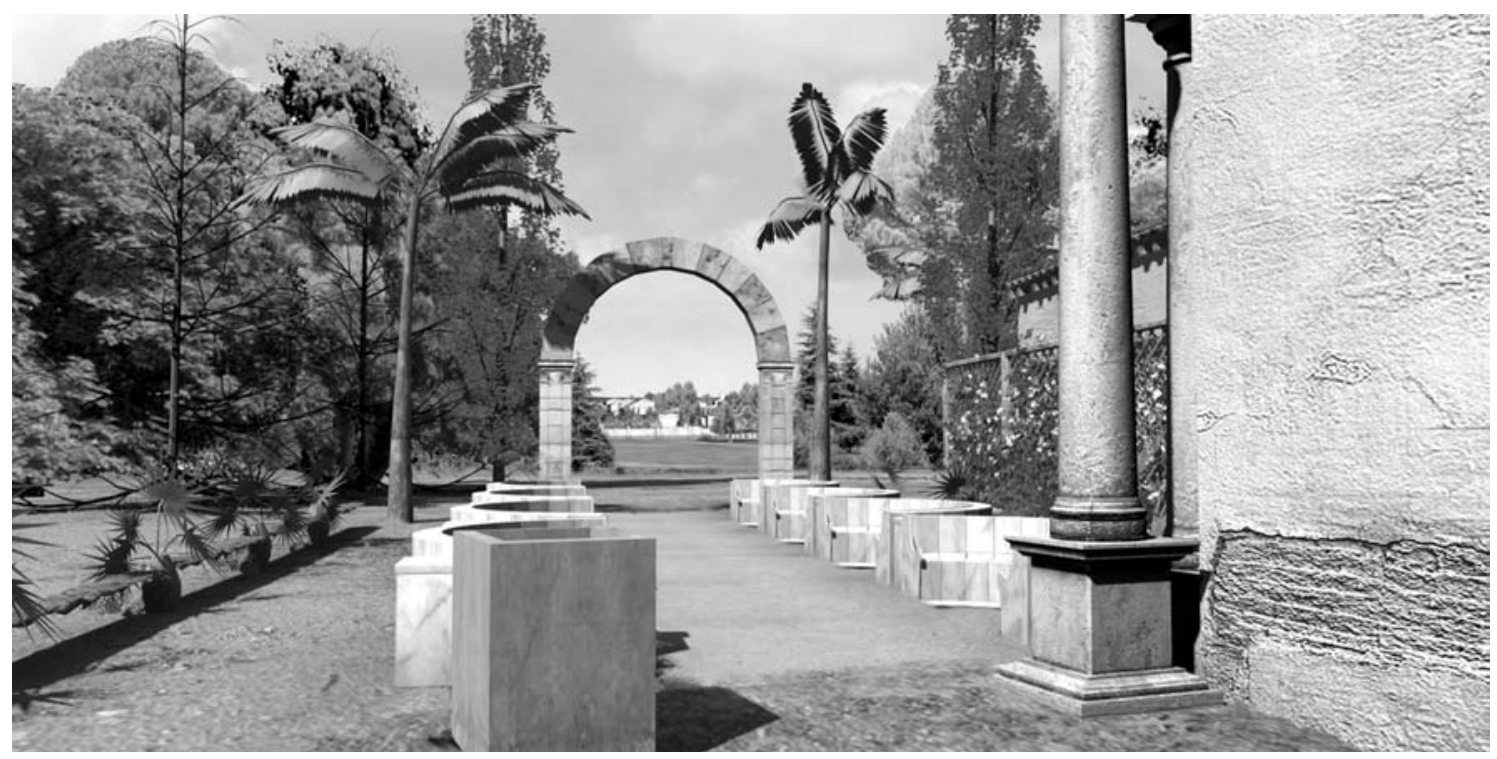

Figura 25. Hipótesis de reconstrucción del efecto paisajístico conseguido entre la schola, el jardín y el Mausoleo de los Anios. Imagen Servicio de Arqueología de A.H. sobre hipótesis de S. Rascón.

de los benefactores, perpetuamente a la vista de los beneficiados. La obra de los evergetas nunca se olvida.

En cuanto a las exedras, tienen unas dimensiones aproximadas de 4'80 $\mathrm{m}$ de longitud que se ofrece al paseo central (el diámetro de la circunferencia que conforman) y $3 \mathrm{~m}$ de fondo (el radio de la parte conservada o construida). La técnica constructiva que se sigue es la elaboración de un zócalo de cantos rodados sobre el que después se levanta un murete de tapial de escasa altura (una media de $45 \mathrm{~cm}$ ). Este murete de tapial, que va a servir para configurar un banco corrido donde sentarse, se cubría después con unos asientos y un frente de placas de otro material más resistente y probablemente más noble. Las dos exedras que se encuentran en posición noroccidental conservaban impresas las huellas de las piezas que sirvieron para preparar los asientos. Las marcas son irregulares, ceñidas a una longitud de $45 \mathrm{~cm}$, que coinciden con el fondo del asiento, pero de anchura diferente, porque van adaptándose a la curva que describe la exedra. Respecto al material que componía este revestimiento, la excavación de esta fachada oriental ha proporcionado restos de ladrillo en pequeñas cantidades, y sobre todo de mármol de dos tipos: blanco, procedente de canteras del Sudeste de España, y ocre-morado procedente de canteras de Soria. Ambos, por otra parte, tienen una presencia habitual en Complutum, y son abundantes en varios edificios del foro ${ }^{34}$. Pensamos por tanto, dado el carácter relevante de este espacio y buscando la

\footnotetext{
${ }^{34}$ Rascón, 2004, vol. II, 15 y ss.
}

concordancia con el refinamiento y lujo empleado en otras partes del edificio, que estarían forradas de mármol, buscando algún tipo de juego cromático entre blancos, ocres y morados. En cada exedra, tras el asiento y abrazándolo completamente se levantaba un segundo muro, que sólo se ha conservado a la cota de cimiento de canto rodado. En realidad sería un respaldo o parapeto para que los usuarios se apoyasen sobre él. Entre cada dos exedras se desarrolla un pequeño murete de canto rodado muy deteriorado donde probablemente se ubicara alguna estructura de carácter perecedero, posiblemente un sistema de vigas de madera, o una estructura de cañas, documentadas en el análisis arqueobotánico, para sostener algún tipo de protección aérea: toldos, o quizá más probablemente un parasol vegetal. De hecho, hemos de hacer referencia a la existencia de cañas (Arundo donax L.), pues sus fitolitos en el jardín evidencian su empleo como parte de pérgolas y probablemente también de tutores para las plantas.

\section{LA CASA DE HIPPOLYTUS, SCHOLA DE UN COLLEGIUM}

La Casa de Hippolytus ofrece diversos elementos de interés para su discusión, si bien en este momento nos interesa su interpretación como sede de un collegium.

Dado el estado de conservación de los restos más antiguos y el objetivo de este trabajo, la interpretación funcional de la Casa de Hippolytus se va a ceñir a la fase III. 
Lo primero que define a nuestro edificio es la atipicidad. Podemos decir qué no es: se trata de un edificio suburbano que está a escasos metros del límite del casco histórico del Complutum bajoimperial y en un primer acercamiento podríamos definirlo como unas termas. Y termas tiene sin duda, aunque lo recortado de su tamaño impide que se puedan considerar como unas termas públicas. Tampoco es una domus con unas termas privadas ya que no existen los espacios característicos de este tipo de viviendas, y nuestro edificio en modo alguno se puede ajustar a los parámetros clásicos de la casa hispanorromana con un peristilo y una serie de habitaciones, un oecus, las piezas que sirven como cubicula, etc. Incluso es complicado identificarla en ese sentido si prescindimos del modelo clásico de casa hispanorromana. Queremos destacar que los alrededores de la Casa han sido sondeados, incluso objeto de un movimiento de tierra de gran envergadura que se debe a la construcción del ya citado Polideportivo Municipal del Juncal entre 1987 y 1990. Por tanto, al margen de los ya citados no hay mas restos significativos pertenecientes al mismo conjunto de la Casa de Hippolytus ${ }^{35}$. Entonces nuestro edificio no es ninguna de las cosas citadas, y será preciso desarrollar un análisis funcional para saber a qué uso puede responder.

La Casa de Hippolytus y el mausoleo de los Anios, que se consideran un bloque a todos los efectos, cumple tres funciones: la primera la lúdica, la segunda la de reunión y la tercera la religiosa.

La función lúdica se desarrolla en dos áreas: primero la más característica del ocio romano de la parte occidental del Imperio, y que se corresponde con un espacio termal. Segundo, la implicada por la cocina y el jardín, que nos remiten a la idea del banquete en reunión. Una buena parte de nuestro edificio se puede entender como unas termas: el patio cubierto central que tiene a su derecha una piscina de agua fría y a su izquierda un estanque trilobulado, y al Sur una zona con calefacción, estructurada en dos caldaria, según los cánones necesarios para cualquier instalación de baños de la época, pero con un tamaño bastante menor de lo habitual para unas termas públicas. Las termas de Hippolytus sirven para el uso de un determinado grupo de personas, no muy numeroso. También incide en lo lúdico la existencia de la cocina, un pequeño horno de adobe que se encuentra ubicado en el praefurnium. Por otra parte, el vertedero de materiales altoimperiales documentado en el propio yacimiento, si bien con una cronología diferente a las estructuras que estamos comentando, se caracteriza también por tener

\footnotetext{
${ }^{35}$ En addendum a este trabajo discutimos la nueva interpretación que García-Entero (2004) realiza de la Casa de Hippolytus, a la que ella considera unas termas suburbanas vinculadas a una domus.
}

abundantes piezas de una vajilla de mesa y con la existencia de restos óseos que indican el consumo de animales muy jóvenes y por tanto muy aptos para ser manjares de lujo. Lujo que por otra parte está presente en todo el edificio, patente en su colección de materiales de alto valor añadido: pintura, escultura y sobre todo, mosaico, especialmente el emblema realizado por Hippolytus o los mosaicos parietales de los que se conservan pocos restos pero en todo caso de probada existencia. El lujo y el deseo de remitirse a elementos exóticos parecen ser muy fuertes entre los propietarios del edificio, ya que además de introducir una decoración acorde con este gusto, y un jardín de corte orientalizante, se recurre a instalar un aviario con especies exóticas de aquellas provincias. En este sentido hay que entender la presencia de los restos de un pelícano en el yacimiento, documentado en el correspondiente análisis de los restos óseos de aves que se recuperaron ${ }^{36}$.

La segunda función que se desarrolla con claridad es la asociativa. Las ocho exedras que se conservan son realmente bancos corridos que permiten que tomen asiento un grupo de individuos, entre cuarenta y ocho y ochenta, con un doble objeto: por una parte la posibilidad de que se utilice como un comedor de verano, y por otra servir de lugar de reunión para debatir asuntos de interés común. Pero además, y lo que consideramos un argumento concluyente, las exedras tienen también una función funeraria y conmemorativa, porque están afrontadas con el mausoleo de la familia de los Anios, promotora del edificio. Además, la función religiosa estaría representada por la estatua de Diana que presidiría la habitación en la que fue encontrada, una sala a la que es posible acceder de forma separada de la zona de ocio y que se encuentra comunicada también con la zona de reunión. También de las cercanías de la Casa de Hippolytus procede un ara dedicado a Hércules por la familia propietaria y/o promotora del edificio, los Anios.

Más allá de lo que significaría interpretar este conjunto como unas termas, lo que sería una lectura parcial y excesivamente simplista (sin duda son unas termas, pero esto no explica este curioso conjunto de termas jardín - theatron y mausoleo funerario; además de termas es, seguro, algo más), creemos que la moderna Arqueología, armada de recursos técnicos muy útiles, puede y debe llegar más lejos en su interpretación. Para ello, las preguntas que intentamos responder son: ¿qué tipos de edificios conocemos en el mundo romano que puedan necesitar de éstas funciones? ¿En cuál, además, éstas definen la misma esencia y dedicación principal del o de los edificios? ¿En qué lugar de una ciudad hispanorromana se venera a divinidades, se recuerda a los evergetas que la construyeron, se demanda un espacio

\footnotetext{
${ }^{36}$ Hernández Carrasquilla, 1992.
} 
de reunión y se generan importantes espacios de ocio, concebidos con un doble criterio de lujo y erudición, y todo ello de forma integrada?

El único tipo de edificio que responde a estas demandas es la sede de una agrupación asociativa, un colegio, con cualquiera de las denominaciones que a lo largo de los siglos se emplearon para definirlo: collegium, schola, aedes..... Estas agrupaciones, tremendamente variadas y diferentes unas de otras, en objetivos, riqueza material, sentido trascendente de su misión, etc. (desde la formalidad de los colegios de Sacerdotes del Culto Imperial, institución canónica, arraigada en la sociedad y en los resortes de poder urbano, a la ligereza de la Asociación de Bebedores de Pompeya, ${ }^{37}$ constituyen fórmulas muy arraigadas en la sociedad romana.

La historiografía ha atendido de forma puntual el problema de los colegios y asociaciones. El texto de referencia, pese a los años que median desde su redacción, sigue siendo el de Waltzing ${ }^{38}$, un exhaustivo trabajo sobre las asociaciones, sus tipos, funciones, etc. a lo largo y ancho del territorio imperial, y al que luego se han añadido otros estudios generalmente de carácter más puntual ${ }^{39}$. En España el trabajo de Santero ${ }^{40}$ necesariamente ha de servir de marco a cualquier investigación sobre colegios hispanorromanos, si bien se avanza decididamente en algunos aspectos: los colegios militares $^{41}$, la arquitectura de las sedes colegiales ${ }^{42}$, incluso los intentos por interpretar en esta clave determinados edificios arqueológicos ${ }^{43}$. Este último aspecto es especialmente complejo, porque la bibliografía referida, incluso este mismo trabajo nuestro, evidencian que no hay una tipología definida para la arquitectura colegial, sino que esta puede ser muy variable.

Las asociaciones en el mundo romano eran numerosas, y probablemente el factor más decisivo para explicar su abundancia es la diferenciación social tan arraigada y a veces extrema. Gran parte de los servicios y de los bienes a los que un hombre de época imperial necesitaba acceder tenían que conseguirse a través de unos mecanismos que

\footnotetext{
${ }^{37}$ Santero, 1978; Waltzing, 1895.

${ }^{38}$ Waltzing $1895-1900$.

${ }^{39}$ Así, De Robertis, 1934. Expresamente sobre colegios juveniles, Ginestet, 1991.

${ }^{40}$ Santero, 1975.

${ }^{41}$ Pérez Yébenes, 1999. Este mismo autor dedica unas líneas a los colegios de jóvenes, destinadas sobre todo a diferenciarlos con claridad de los militares.

${ }^{42}$ Carrillo Díaz-Pinés, 1995; Subías Pascual, 1994, ambos desde ópticas diferentes.

${ }^{43}$ Por ejemplo, para Itálica, Rodríguez Hidalgo, 1991 -aunque la interpretación de la Casa de las Exedras sigue siendo problemática-; también la misma Casa de Hippolytus, en Rascón y Polo, 1996.
}

difieren mucho de los actuales. El Estado occidental del siglo XXI (llamado Estado del Bienestar) proporciona una serie de servicios que el Estado imperial romano no contemplaba en absoluto ¿Cómo se accede entonces a ayudas sociales, a privilegios, a puestos de trabajo? Fundamentalmente a través de dos elementos como son la amistad, entendida en el sentido clásico más estricto, y el patronato. El intercambio tiene sentido sobre todo entre las clases altas: un patrono o un amigo protege siempre a un individuo de posición social levemente inferior, del que siempre se espera conseguir algo a cambio: apoyo en determinadas cuestiones, en una carrera política u otros beneficios diversos. Las clases más humildes, artesanos, comerciantes, militares, no tienen esta posibilidad porque poco tienen que ofrecer individualmente. Pero se abre una vía para ellos a través del asociacionismo: una serie de individuos, generalmente unidos por un factor determinado, frecuentemente su adscripción social y / o su actividad económica se unen entre sí para ser capaces de acceder a beneficios que de otra forma no pueden conseguir, porque como grupo suman una fuerza cuyo control resulta deseable para las clases sociales más elevadas ${ }^{44}$, y el propio Estado podía, sobre todo en los últimos años de la República y primeros del Imperio, extraer una utilidad pública de su existencia ${ }^{45}$. Así ocurre claramente con el grupo de los tria collegia (dendrophori, centonari y fabri) que aglutinan tres oficios considerados imprescindibles para la ciudad de Roma, necesidad extrapolable a la mayoría de las poblaciones de tamaño mediano del Imperio, lo que justifica su legitimación incluso en una época como la Julio-Claudia, donde la legislación es muy restrictiva para con el fenómeno asociativo, seguramente porque aún existe el recuerdo de las movilizaciones políticas de finales de la República. Sin duda, estas necesidades encuentran un aglutinante en la expresión profesional de dichos grupos, lo que explica que su carácter tenga algunos puntos de contacto con los gremios medievales: el hombre romano se define principalmente por su ocupación.

Esto no debe llevarnos a una lectura simplista de la actividad colegial, porque a partir de la premisa citada la realidad asociativa se complica extremadamente y se instala en todos aquellos grupos que se identifican con un factor determinado, incluso cuando el factor es su relación con el poder -es decir, entre ciudadanos medianamente acomodados- lo que los convertiría, de hecho, en elementos de presión política nada desdeñables: los colegios militares, los sacerdotes augustales, los propios colegios de los jóvenes, tienen un peso muy considerable en las ciudades en que se instalan.

\footnotetext{
${ }^{44}$ Ver, por ejemplo, Garnsey y Saller, 1990, 186 y ss.

${ }^{45}$ Sobre esta utilidad pública de los colegios, que parece fraguarse en las últimas décadas del siglo I a.C. y primeras del I d.C., consultar Subías, 1994, 86 y ss.
} 
La mayoría de los colegios son los de tenuiores, asociaciones para pobres ${ }^{46}$. Para éstos, los servicios que se ofrecen son muy elementales: a cambio del pago de una cuota, y de las aportaciones económicas que realizase el patrono, se accede a un enterramiento digno: el colegio organiza los sepelios del difunto y los colegiados se comprometen a formar parte del duelo y de las pompas para honrar al difunto, lo que es de la mayor importancia en el concepto clásico del tránsito a la vida de ultratumba. Es ésta, por cierto, una actividad que también se extiende a colegios con un mayor nivel económico. Los colegios en el siglo I a.C. y I d.C. parecen tener, por lo general, un objetivo cultual y funerario, que responde a necesidades concretas de individuos socialmente poco favorecidos, pero que grupos más poderosos tampoco desdeñan.

Otro factor de actividad, el principal en muchos colegios, es el cultual: las asociaciones tenían una advocación concreta y están dedicados a una u otra divinidad. Muchos autores han querido interpretar que existe una realidad material en los colegios que va cambiando a lo largo del Imperio: para Subias, las sedes del siglo I y II responden a necesidades básicamente religiosas; a partir del siglo II se potencian los espacios destinados a actividades conviviales, y la arquitectura de los colegios profesionales expresa la voluntad de las corporaciones de una proyección a la altura de las circunstancias $^{47}$.

También sabemos que los colegios, independientemente de su nivel económico, organizan comidas periódicas. Si es un colegio de gente humilde, esto permite acceder a determinados tipos de alimentos que de modo privado los colegiados no pueden costearse, permitiéndose así que entren en la dinámica social, definitoria de la cultura romana, del banquete. Un tema atractivo, el de acercar el acto civilizado por excelencia, la cena, a grupos de inferior cultura, y así lo percibían los propios romanos, que gustan de expresar lo que ellos entienden como una paradoja social en la literatura o en las artes plásticas: La cena de Trimalción, uno de los episodios más célebres que la literatura romana latina nos ha ofrecido $^{48}$, expresa con aire aristocrático esta contradicción entre un acto noble, el banquete, y la baja procedencia e incultura del anfitrión. Incluso la musivaria lo refleja en un pavimento del Djem, de la primera mitad del siglo III d.C. donde los comensales, sentados a la mesa como señores, expresan en el tono grosero de su conversación su baja procedencia. En opinión de Yacoub, podríamos estar ante una cena ofrecida a un determinado colegio de

\footnotetext{
${ }^{46}$ Sobre los tipos de colegios, consúltese la obra de Waltzing, 1895-1900.

47 Subías, 1994,103 - 105.

${ }^{48}$ Petronio, XXXI y ss.
}

los varios existentes entre el colectivo de los bestiarios, los bien documentados Taurisci ${ }^{49}$.

Por otro lado el banquete es un acto de representación y cohesión social, así que no cabe duda de que no sólo se prodigaba en los colegios de inferior rango, sino que también hubo de ser sistemático en los de mayor nivel social y económico. Más aún, los banquetes estaban ligados a ceremonias públicas y privadas, vinculadas a fiestas, eventos y juegos relacionados en las capitales con hechos imperiales, y en el resto de las ciudades con otros aspectos propios de la vida municipal ${ }^{50}$. Pero los banquetes tienen sobre todo un carácter comunal y asociativo, lo que indica claramente que también los colegios proporcionan un lugar de reunión: además de otras necesidades, el carácter asociativo de estos centros, y su funcionamiento que es muchas veces imitativo de las estructuras políticas y de representación de la propia ciudad, obligaría a que existiese un lugar para determinadas actividades colegiadas.

Cierto tipo de colegios, principalmente los de alto nivel económico, son también lugares donde se ofrecen ocio y entretenimiento. El ocio está representado en el mundo romano por los complejos termales, que como se verá a continuación están presentes con cierta frecuencia en la arquitectura de las sedes colegiales. A la par, son estas sedes un lugar de encuentro digno y lujoso para los colegiados, y reúnen un rico mobiliario que se manifestaría en mosaicos, en revestimientos de mármol, en mobiliario de piedra, en estatuaria: los testimonios son numerosos, y existe un ejemplo cercano, español, una de las pocas sedes colegiales documentadas en la Hispania romana: el collegium fabrum de Tarraco $^{51}$, con un rico repertorio escultórico que sigue la línea de otras ilustres sedes colegiales, esta vez del ámbito propiamente romano, como la Casa de los Triclinios.

Hasta aquí, es evidente que las actividades de un colegio de alto nivel se relacionan directamente con las funciones expresadas en la lectura arqueológica de la llamada Casa de Hippolytus. Pero cabe también que el análisis arqueológico se refiera igualmente a las realidades materiales que, hasta la fecha, nos han proporcionado las excavaciones sobre establecimientos susceptibles de esta interpretación.

La realidad arqueológica de los colegios es atípica, y debe entenderse en razón de las funciones que en ese colegio se desarrollasen. La capacidad económica de los colegios variaba, como también lo hacían sus necesidades y el volumen de sus actividades. Por consiguiente no hay una arquitectura arquetípica para la sede colegial (la

\footnotetext{
49 Véase la argumentación de Yacoub, en 1995, 269 y ss.

${ }^{50}$ Las referencias bibliográficas son muy abundantes: Santero, 1975; Subías, 1994, 90 y ss.

${ }^{51}$ Koppel, 1988; Carrillo-Díaz, 1995.
} 
schola, o cualquiera de los apelativos que recibe a lo largo de los siglos y de la geografía imperial), pero sin embargo hemos asistido en la bibliografía más reciente a la aparición de una serie de trabajos sobre arquitectura de las corporaciones en todo el Imperio, y la conclusión tiende a consagrar la difícil caracterización de estos edificios. Principalmente hay que citar la obra de 1995 de Carrillo-Díaz, quien recoge los edificios que con más claridad pueden interpretarse como tales sedes; un trabajo que contribuye a llenar un vacío historiográfico, aunque curiosamente no se recoge el problema planteado en lugares de obligada referencia, como la Casa de las Exedras y la de los Pájaros de Itálica, en España, o algunas sedes muy notables de la mitad oriental del Imperio, como el Heroon de Diodoros Pasparos de Pérgamo $^{52}$. Es en este marco de reconocimiento creciente de la realidad arqueológica de las asociaciones romanas en el que se incluye la identificación de nuestro edificio complutense.

Para complicar nuestra tarea, la mayoría de los edificios interpretados como sedes colegiales pertenecen a Roma y a su entorno más inmediato, cercano a la problemática social, cultural y arquitectónica de la capital, que no coincide a veces con la provincial. Más aún, proceden en concreto de entornos muy bien conservados, como Ostia. También otras sedes, pertenecientes a entornos provinciales, han podido ser interpretadas como tales gracias a su magnífico estado de conservación: se ubican en el Norte de África (Cartago, Mactar...) o en Asia Menor (el ya citado Heroon de Pérgamo).

En España la identificación de sedes colegiales es muy escasa. Santero ${ }^{53}$ realiza uno de los primeros intentos de interpretación referido a la exedra o schola de los Cultores Minervae de Tarraco, a la que se refiere como una sala semicircular de reuniones y conversaciones, con bancos colocados en semicírculo (es decir, el mismo mecanismo que en la Casa de Hippolytus), bien es verdad que sin contar con argumentos arqueológicos sólidos. El collegium fabrum, también de Tarraco, se ha reconocido en función de su epigrafía y su programa escultórico, pero poco puede decirse de su planta, aparentemente un edificio urbano, de peristilo porticado en tres de sus lados ${ }^{54}$.

Más explícitos son los restos arqueológicos de la Casa de las Exedras en Itálica, interpretada tradicionalmente como domus, pero con una reciente relectura de Rodríguez Hidalgo ${ }^{55}$, fundamentada en dos factores: la

\footnotetext{
${ }^{52}$ Filgis y otros, 1985/86.

${ }^{53}$ Santero, 1975.

${ }^{54}$ Carrillo Díaz, 1995, 59 y ss; Koppel, 1988, passim.

${ }^{55}$ Rodríguez Hidalgo 1991, 296 y ss; también Roldán, 1991, 311, nos hablan de un carácter "especial", refiriéndose a la función de este edificio.
}

extrema importancia de las áreas de uso público o semipúblico, como las termas y las letrinas, y la importancia de la cocina, así como en el escaso interés por las zonas privadas, principalmente el cubiculum o el larario. Sin embargo, no existe acuerdo unánime en la aceptación de esta interpretación.

A pesar de todo lo dicho, Hermanssen ${ }^{56}$ ha diseñado un modelo identificativo local de arquitecturas colegiales para la ciudad de Ostia, lo que se debe al elevado volumen de documentación que procede de esta ciudad, en realidad un anexo de Roma. Este autor distingue en las sedes de corporaciones unos rasgos definitorios: monumentalidad, centros de culto, cocinas, espacios amplios para reuniones y banquetes.

A pesar de lo específico del estudio de Hermanssen, aplicado a una ciudad concreta con una documentación arqueológica excepcional, es posible proyectar fuera de la Península Itálica estos rasgos arquitectónicos, que se repiten en las diferentes sedes identificadas tanto en Italia como fuera de ella, y a las que habría que añadir una nueva: la relativa abundancia de espacios termales y de letrinas sobredimensionadas:

Primero, las áreas domésticas características están ausentes por completo y muchos edificios no responden a los esquemas clásicos, de peristilo: el Aula de los mensores en Ostia ${ }^{57}$, el edificio de Eumachia (Pompeya), la schola iuvenum (Mactar, Túnez) ${ }^{58}$. Incluso cuando las sedes se planifican desde una planta de casa con peristilo, se da la circunstancia de que hay espacios de la tipología doméstica muy poco o nada representados, como los cubicula, o el lararium. Constatamos que en la Casa de Hippolytus y su entorno no existe tampoco ningún argumento para una posible identificación doméstica.

Segundo, aparecen conjuntos termales demasiado pequeños para ser unas termas públicas urbanas, y además están asociados a otros espacios que tampoco pueden interpretarse como casas privadas, lo que imposibilita que se trate de pequeños balnea domésticos. Especialmente es imposible en lugares como la Casa de Hippolytus, donde no hay una domus para vincularlos, y sí que existe, en cambio, un mausoleo funerario.

Estos complejos termales se encuentran muy bien representados en la domus de los Dioscuros de Ostia, tradicionalmente referida como un ejemplo de la casa privada tardía ostiense ${ }^{59}$, pero reinterpretada a la luz de trabajos mas recientes ${ }^{60}$, que la consideran un establecimiento semipúblico, empleado por un colectivo restrin-

\footnotetext{
56 Hermanssen, 1982.

57 Hermanssen, 1982 y Carrillo - Díaz, 1995.

58 Picard, 1957. Romanelli, 1964.

59 Becatti, 1948.

${ }^{60}$ Pavolini, 1986; ver principalmente el desarrollo argumen-
} tal de Subias, 1993. 
gido y conectado con los juegos que se celebraban en la ciudad en honor de los Dioscuros, probablemente, quizá, una corporación de atletas o de jóvenes. Este edificio desarrolla principalmente los espacios termales y los de servicios, con zonas que están planteadas para el ocio, el tránsito de grupos medianamente numerosos y la representación. Acorde con esto, el esfuerzo y el dinero invertidos en un programa decorativo complejo, con mosaicos, pinturas murales, fuentes y zonas con calefacción, entre los que sobresale el mosaico de los Dioscuros que da nombre al complejo edilicio. Estas termas, además, se fechan en época tardía, para lo que existen varias hipótesis, que no vamos a entrar a discutir, y que oscilan entre mediados del siglo IV y el primer cuarto del V d.C. Este conjunto de circunstancias hace que estemos ante el paralelo más explícito con respecto a la Casa de Hippolytus.

En otras sedes corporativas existen también baños: así ocurre con la schola iuvenum de Mactar, donde todo el ala oriental está ocupada por un complejo termal, con piscinas, fuentes y letrinas, que se fechan en el siglo I, aunque la schola cuenta con remociones en época severiana y a finales del siglo III. Lo mismo ocurre en la Casa de Baco de Djemila, con un importante complejo termal ${ }^{61}$. En este marco también resulta totalmente congruente la lectura de nuestra Casa de Hippolytus como sede colegial.

En tercer lugar, es habitual la insistente presencia de letrinas y pozos, con frecuencia (y al igual que ocurre en el edificio complutense) sobredimensionadas en tamaño o con una decoración especialmente lujosa: la citada schola iuvenum de Mactar, la sede de los stuppatores de Ostia, de época tardoseveriana ${ }^{62}$ o la también ostiense sede (aula) de los mensores ${ }^{63}$, incluso la Casa de las Exedras de Itálica, con el conocido mosaico de tema nilótico.

Una cuarta característica es la presencia de zonas para reuniones y banquetes, a veces ligadas directamente al recuerdo de los patronos, de los evergetas que financian el complejo. Es este uno de los aspectos mas desarrollados en la Casa de Hippolytus, con el jardín de inspiración orientalizante y dotado para acoger una reunión de numerosas personas, que ocupa el ala oriental, afrontado con el mausoleo de la familia de los Anios. Estos espacios los hallamos en el Heroon de Pérgamo, con una sala dedicada al héroe, Diodoros Pasporos, junto a la que se abre un pequeño theatron, generalmen-

\footnotetext{
${ }^{61}$ Romanelli, 1964, 16, Ellis, 1983, 143 y ss; BlanchardLemée, 1984.

${ }^{62}$ Hermanssen, 1982; Pavolini, 1988; Carrillo-Díaz, 19.95, 36 y ss.

${ }^{63}$ Hermanssen, 1982; Pavolini, 1988; Becatti, 1961;Carrillo-Díaz, 1995.
}

te interpretado como un odeón, pero que en cualquier caso es un lugar destinado a reuniones de un colectivo vinculado a la memoria de aquel personaje ${ }^{64}$. También en la citada Casa de Baco de Djemila, con jardines y un gran comedor ${ }^{65}$, la schola iuvenum de Mactar, o las sedes de los stuppatores, de los Augustales y de los fabri navales de Ostia ${ }^{66}$.

La quinta característica es la existencia de lugares para el culto: aquí, los ejemplos se multiplican porque el hábito es esencial en cualquier colegio, pues ésta es una función primordial y en todos los casos hay una advocación hacia determinado culto: en Ostia, las sedes de los stuppatores, de los Augustales y de los fabri navales (la también llamada schola de Trajano) ${ }^{67}$. En Pérgamo, el Heroon de Diodoros Pasporos ${ }^{68}$. En Tarraco, el collegium fabrum. En Alesia, una corporación artesanal, el llamado Monument d'Ucuétis ${ }^{69}$.

Finalmente, en sexto lugar, contamos con referencias epigráficas al patrono, aquel personaje bien ubicado en las redes políticas locales y que financia las actividades del colegio y frecuentemente la construcción de la sede: en Mactar, una inscripción documenta las remodelaciones que en la schola realiza nada menos que el procónsul de Africa, M. Aurelius Aristobulus. Por razones obvias, el número de inscripciones recuperadas es limitado (desgraciadamente los epígrafes recuperados en posición original son muchos menos de los que quisiéramos los arqueólogos). Parece indudable que este hábito epigráfico se corresponde con la lectura de la inscripción del mosaico de Hippolytus, y con la declaración de que el edificio pertenece a los Anios (pues así ha de leerse el término ANNIORUM). La fórmula elegida se vincula a los hábitos epigráficos romanos bajoimperiales, donde en las obras de rehabilitación o nueva construcción las fórmulas evergéticas propias de la aristocracia local altoimperial desaparecen en favor de otros mecanismos: alusiones literarias, presencia de altos funcionarios del Estado, etc. Es más, los Anios insisten en su presencia epigráfica en nuestro colegio mediante la inscripción recuperada en 1871 en que Gayo Anio y Magia Atta efectúan una dedicatoria a Hércules en cumplimiento de un voto (posiblemente, lo que se ofrece es un ara de sacrificios, que es la pieza recuperada). Además, y lo que es excepcional, es que el mausoleo de la familia se encuentra formando parte del mismo complejo que la

\footnotetext{
${ }^{64}$ Filgis y otros, 1985/86.

${ }^{65}$ Romanelli, 1964, 16.

${ }^{66}$ Hermanssen, 1982; Pavolini, 1988; Becatti, 1961; Carrillo-Díaz, 1995.

${ }^{67}$ Hermanssen, 1982; Pavolini, 1988; Becatti, 1961; Carrillo-Díaz, 1995.

${ }^{68}$ Filgis y otros, 1985/86.

${ }^{69}$ Martin Varene, 1973, 155 y ss.
} 
familia funda, siendo perfectamente visible desde él, es más vinculándose paisajísticamente con su jardín.

Por si los argumentos expuestos hasta ahora fueran pocos, queremos dejar constancia de la relación de las grandes exedras semicirculares, empleadas como lugares de reunión, con las actividades convivales en colegios y otros entornos funerarios. Se trata de una práctica común en la arquitectura romana, tan conocida que algunos ejemplos son muy célebres e incluso populares: en el siglo I d.C. al menos tres relevantes mausoleos funerarios de Pompeya (figura 26) cuentan con magníficas exedras, bancos corridos de piedra, monumentalizados e incluso con su correspondiente dedicación epigráfica. Estos conjuntos de exedras han servido como inspiración a célebres pintores de finales del XIX y principios del XX (así Alma-Tadema), y forman parte de la recreación idealizada que el hombre moderno hace de la arquitectura clásica. La misma solución de exedras existe en el collegium iuvenum de Mactar, donde la arquitectura reconstruye un salón para reuniones concebido arquitectónicamente como el grupo de la Casa de Hippolytus (aunque no vinculado a un jardín, y esta vez los bancos no son de piedra ni están monumentalizados como los pompeyanos). Incluso la arquitectura palatina del siglo $\mathrm{V}$, en Constantinopla, nos obsequia con el comedor de exedras semicirculares del Palacio de Lausos ${ }^{70}$.

Parece por tanto que la Casa de Hippolytus cumple todos los parámetros posibles para no corresponderse con ningún otro tipo de edificio y sí con la sede de una agrupación colegial.

Más aún, y aunque este aspecto es más discutible, pensamos que debe tratarse de la sede de una corporación determinada, el collegium iuvenum complutense. Nuestros argumentos son los siguientes:

Dos hechos aluden a un edificio para uso de un grupo perteneciente a las clases cultas y acomodadas: la riqueza y elevado coste de la decoración y el carácter erudito tanto del programa iconográfico como del jardín, que se acogen a un tema literario, los lugares paradisíacos y el mundo bucólico. Esto excluye a las asociaciones de tenuiores y, en una ciudad de mediano tamaño como Complutum, a los colectivos de comerciantes y artesanos. El carácter del edificio se ajusta a grupos de elevada posición, como los augustales o los jóvenes.

Hay tres edificios que se quieren interpretar como sedes de agrupaciones juveniles: la Casa de las Exedras de Itálica (este con bastantes reparos), la Casa de los Dioscuros de Ostia y la schola de Mactar. En los tres, como en Complutum, las termas tienen una posición preponderante.

Además el ocio, entendiendo como tal la formación física, es una de las actividades que distinguirían a estos

${ }^{70}$ Krautheimer, 1981 colectivos $^{71}$. El collegium iuvenum agrupa a los hijos de las clases altas de las ciudades para introducirlos en determinados comportamientos sociales. Determinados collegia desarrollaban en sus respectivas ciudades tareas que se referían al embellecimiento de la ciudad y a las manifestaciones sociales en las mismas, como participación en fiestas y procesiones, organización de determinados acontecimientos, incluso hay quien propone una vocación paramilitar, para garantizar el orden en determinadas circunstancias. Posiblemente también cumplieran una cierta función educativa. Los socios son jóvenes, aunque muchas veces no tanto, puesto que se han documentado en algunos casos socios de hasta cuarenta años de edad, pero en todo caso hijos de la élite de la ciudad, de decuriones, principales o de cualquier persona capaz de desempeñar una magistratura (como libertos acomodados). Los colegios son además centros de presión y de poder importantes, porque en ellos confluyen las familias más relevantes. Esta demostrado incluso que en muchos colegios los mismos magistrados que representan a la asociación son también magistrados de la ciudad, con lo cual hay una importante sintonía entre lo que se decide en el colegio y la gestión pública que en la ciudad se desarrolla.

El ejercicio físico y la caza entrarían en una lista de actividades colegiadas para jóvenes, que contribuyen a la formación del aristócrata. La realidad arquitectónica de todo ello, en Oriente, son las palestras, que por otro lado en Occidente están poco presentes en la realidad arqueológica urbana, y las termas. Nada tiene de extraño que en Hispania sea la realidad termal la que claramente se imponga.

El culto a Diana, como diosa de la caza, acto representativo del ocio de las clases altas en la tardorromanidad, estaría presente en el Colegio de Complutum como en otros colegios juveniles. También el culto a Hércules, mediante la dedicatoria de Magia Atta y Gayo Anio. Coincide este doble culto con los datos proporcionados por el estandarte de Pollentia ${ }^{72}$, actualmente en el MAN, que se ha identificado como emblema del collegium iuvenum de dicha ciudad balear: en él están presentes Diana, Hércules y el Genio de la Juventud (paradójicamente, un hombre maduro y barbado). Entre los investigadores no hay duda de que las advocaciones a Diana y Hércules serían las principales de los colegios de jóvenes ${ }^{73}$, aunque otras también se han documentado, como la de Marte Augusto (congruente con la virtus como

\footnotetext{
71 Santero, 1975, dedica algunos párrafos a estos colegios; es sobre todo Jaczynowska, 1970, quien desarrolla un extenso estudio.

${ }^{72}$ Arce, 1980

73 En este aspecto hay un acuerdo unánime. Ver Santero, 1975, Arce, 1980 y Jaczynowska, 1970.
} 
valor moral que desea transmitirse a los jóvenes) en la schola iuvenum de Mactar.

Por último, y en este contexto ${ }^{74}$, nos parece significativo que sean infantes los protagonistas del programa iconográfico del colegio complutense: niños en la barca que pesca en el Mediterráneo de nuestro mosaico, cupidos acompañando el triunfo de Venus de la pintura mural.

\section{BIBLIOGRAFÍA}

ARCE, J. (1980): "El significado religioso del estandarte romano de Pollentia (Mallorca)". La Religión Romana en Hispania. Madrid.

BALIL, A. (1960): “Arte helenístico en el Levante Español: Mosaicos con representaciones de peces hallado en Ampurias". Boletín Real Academia de la Historia, CXLVI, II, pp. 267-310. Madrid.

BECATTI, G. (1948): "Case ostiensi del tardo impero". BdA XXXIII, pp. 102-128 y 197-224.

BICKEL, E. (1982): Historia de la Literatura Romana. Madrid.

BOBADILLA, M. (1969): "El mosaico de los peces de la Pineda (Tarragona)”. Pyrenae, 5, pp. 141-159.

CARRILLO DÍAZ-PINÉS, J.R. (1995): "Las sedes de corporaciones en el mundo romano. Un problema de identificación arqueológica". Anales de Arqueología Cordobesa, 6. Córdoba.

CORTÉS ISLAS, M.E. y RAMIREZ GARCIA, F.P. (1992). "Rescate de las antiguas medidas mexicanas", Boletín de la Sociedad Mexicana de Física, 6 (1), pp. 4-11.

FERNANDEZ-GALIANO RUIZ, D. (1984b): Complutum. II. Mosaicos, Excavaciones Arqueológicas en España, 138, Madrid.

FILGIS, M.N., RADT, W., HILLER, H., HÜBNER, G. y WÖRRLE (1985/86): Altertümer von Pergamon, XV. Die Stadtgrabung. 1. Das Heroon. Berlin.

GARCÍA-ENTERO, V. (2004): "Nueva propuesta interpretativa de la llamada Casa de Hippolytus de Complutum (Alcalá de Henares, Madrid). Un complejo termal suburbano". Archivo Español de Arqueología, 77, 2004, pp. 143-158.

GARNSEY, P. y SALLER, R. (1990): El Imperio Romano. Economía, Sociedad y Cultura. Barcelona.

GINESTET, P. (1991): Les Organisations de la jeunesse dans l'Occident Romain. Bruselas.

GÓMEZ PALLARÉS, J. (2001): "Apostillas al estudio de la inscripción musiva de Hippolytus (Complutum, Alcalá de Henares, Madrid)". Lucentum, XVII XVIII, 1998 - 1999. Universidad de Alicante.

\footnotetext{
${ }^{74}$ Solo en este contexto. En realidad, los niños y puti pueden aparecer con otros significados en contextos diferentes.
}

GRIMAL, P. (1990): I giardini di Roma antica. Roma. GUIRAL PELEGRÍN, C. (e.p.): "Pinturas murales". La Casa de Hippolytus. Schola de una agrupación colegial. Cuadernos de Patrimonio Histórico de Alcalá de Henares, 3.

HERMANSSEN, G. (1982): Ostia. Aspects of Roman city life. Edmonton.

HERNÁNDEZ CARRASQUILLA, F. (1992): Las aves de la villa romana de Hippolytus. Campaña 199091. (Inédito).

JACZYNOWSKA, (1970): "Les organisations des iuuenes et l'aristocratie municipale au temps de l'Empire romain". Recherches sur les estructures socials dans l'antiquité classique. Caen, pp. 265-266.

JASHEMSKI, W. (1993): The gardens of Pompeii, Herculaneum and the villas destroyed by Vesubius. New York.

KNAPP, R. (1992): Latin Inscriptions from Central Spain. Berkeley - Los Angeles - Oxford.

KOPPEL, E.M. (1988): La schola del collegium fabrum de Tarraco y su decoración escultórica. Faventia, Monografies, 7. Barcelona.

KRAUTHEIMER, R. (1996): Arquitectura Paleocristiana y Bizantina. Madrid.

PAVOLINI, C. (1986): "L'edilizia commerciale e l'edilizia abitativa nel contesto di Ostia tardoantica". Società romana e impero tardoantico II: Roma: política economica paessaggio urbano. Roma-Bari, pp. 239-297.

PÉREZ YÉBENES, S. (1999): Collegia militaria. Asociaciones militares en el Imperio Romano. Madrid.

PICARD, G-CH. (1957): "Civitas Mactariana". Karthago, VIII. Túnez.

RASCÓN MARQUÉS, S. (1995): La ciudad hispanorromana de Complutum. Cuadernos del Juncal 2. Alcalá de Henares.

RASCÓN MARQUÉS, S. (1998): Complutum: Roma en el Interior de la Península Ibérica. Catálogo de la Exposición. Alcalá de Henares, 18 de Mayo a 26 de Julio. Alcalá de Henares, p. 268, 146-153,

RASCÓN MARQUÉS, S. (2000): "La Casa de Hippolytus. Un recurso expositivo y didáctico sobre el patrimonio arqueológico de Alcalá de Henares". Actas del I Encuentro Internacional Ciudad, Arqueología y Desarrollo. La musealización de los yacimientos arqueológicos. Alcalá de Henares, septiembre de 2000._Alcalá de Henares.

RASCÓN MARQUÉS, S. (2001): “El Mediterráneo y los lugares paradisíacos en la cultura material de la Meseta durante los últimos siglos del Imperio". Acta Antiqua Complutensia, II. Ocio y Esperctáculo en la Antigüedad Tardía. Alcalá de Henares, pp. 265-283.

RASCÓN MARQUÉS, S. (2004): Complutum hispanorromano. Tesis doctoral. Universidad Autónoma de Madrid. 
RASCÓN MARQUÉS, S. (ed): Arqueología de los Jardines Romanos en España. Ayuntamiento de Alcalá de Henares - Universidad de Alcalá.

RASCÓN MARQUÉS, S. y POLO LÓPEZ, J. (1996): "La casa de Hippolytus (Alcalá de Henares, Madrid): la schola de un colegium iuvenum complutense", V Encuentro de Historiadores del Valle del Henares, pp. 61-77, Guadalajara.

RASCÓN MARQUÉS, S. y SÁNCHEZ MONTES, A.L. (2006): "Complutum, la ciudad de las Ninfas". Civilización. Un viaje a las ciudades de la España antigua. Catálogo de la exposición. Alcalá de Henares, 2006-2007. Alcalá de Henares.

RASCÓN MARQUÉS, S. y SÁNCHEZ MONTES, A.L. (e.p.): "El urbanismo de la ciudad romana de Complutum (Alcalá de Henares, España) en el contexto urbano de Hispania antigua". JRA. Chicago.

RASCÓN MARQUÉS, S.; MÉNDEZ MADARIAGA, A. y SÁNCHEZ MONTES, A.L. (1993): "El mosaico del Auriga de la villa romana de El Val (Alcalá de Henares, Madrid) y las carreras de carros en el entorno complutense". Espacio, Tiempo y Forma, Serie I, 6. Madrid, pp. 303-341.

RASCÓN MARQUÉS, S. , POLO LÓPEZ, J., GÓMEZ PALLARÉS, J. y MÉNDEZ MADARIAGA, A (1998): "Hippolytus: estudio de un nuevo mosaico del género de pesca y con inscripción procedente de Complutum, Alcalá de Henares, Madrid." Lucentum, XIV - XVI, 1995-97. Universidad de Alicante.

RASCÓN MARQUÉS, S., SÁNCHEZ MONTES, A.L., LUNA LLOPIS, J., MÉNDEZ MADARIAGA, A., y POLO LÓPEZ, J., (1998): "Musivaria complutense". Complutum: Roma en el Interior de la Península Ibérica. Catálogo de la Exposición. Alcalá de Henares, 18 de Mayo a 26 de Julio. Alcalá de Henares, pp 146-153.

ROBERTIS, F.M. de (1955): Il fenomeno associativo nel mondo romano. Nápoles.

RODRÍGUEZ HIDALGO, J.M. (1991): “Dos ejemplos domésticos en Traianopolis (Itálica). Las casas de los Pájaros y la Exedra". La casa urbana hispanorromana. Zaragoza, pp. 291 - 302.

ROLDÁN GÓMEZ, L. (1991): "La Casa de la Exedra de Itálica (Santiponce, Sevilla), un intento de valoración espacial a través de las técnicas constructivas" La casa urbana hispanorromana. Zaragoza, pp. 303 - 311.

ROMANELLI, P. (1964): "A proposito della "Schola juvenum" di Mactaris". Cahiers tuniciennnes XII, 45 - 46. Tunis, pp. 11-17.

SÁNCHEZ MONTES, A.L. (2000): "Proyectos formativos e inserción laboral relacionados con el Patrimonio Histórico". 1er Congreso Internacional Ciudad, Arqueología y Desarrollo. La Musealización de los Yacimientos Arqueológicos. Alcalá de Henares, pp. $35-47$
SÁNCHEZ MONTES, A.L. y RASCÓN MARQUÉS, S. (2004): "La Casa de los Grifos. Una nueva domus de Complutum". Actas del IX Encuentro de Historiadores del Valle del Henares. Guadalajara, 2004. Guadalajara.

SANTERO SANTURINO, J.M. (1978): Asociaciones populares en Hispania romana. Sevilla.

SUBIAS PASCUAL, E. (1994): "Las sedes colegiales en época romana: problemas de tipología arquitectónica". Butlletí Arqueològic, 16. Tarragona.

TRESSERRAS, J.J., MATAMALA, J.C. y FRANCESC BURJACHS, F. (2002): El jardín romano bajoimperial de la Casa de Hippolytus en Complutum (Alcalá de Henares, Madrid): una posible recreación a partir de las investigaciones arqueobotánicas (pólenes y fitolitos). Informe inédito. Depósito en el Servicio de Arqueología del Ayuntamiento de Alcalá de Henares.

VALLEJO GIRVÉS, M. (2005): El solar de Complutum. Memoria histórica de la Arqueología en Alcalá de Henares. Cuadernos de Patrimonio Histórico de Alcalá de Henares, 1. Alcalá de Henares.

WALTZING, J.P. (1895-1900): Étude historique sur les corporations professionelles chez les romains. Lovaina.

YACOUB, M. (1995): Splendeur des mosä̈ques de Tunisie. Tunis .

\section{ADDENDUM: Respuesta a la Dra. García Entero}

Tradicionalmente hemos defendido la hipótesis, ampliamente desarrollada en el trabajo al que este addendum acompaña, de que la Casa de Hippolytus es la sede de una agrupación colegial complutense. Recientemente García-Entero ha propuesto una interpretación distinta, según la cual se trataría de un complejo termal suburbano, concretamente un balneum relacionado con una mansión extramuros: “...los restos de la Casa de Hippolytus interpretados, como veremos, como parte de la sede de un collegium iuvenum, y que creemos, pueden ser vinculados con una importante domus suburbana de la que apenas conocemos su balneum" (García-Entero, 2004, 145). La autora, notable conocedora de los edificios termales, desarrolla un meritorio trabajo orientado hacia los aspectos que ella mejor conoce, los de la arquitectura termal. Es quizá esta orientación parcial, la que hace que su lectura del yacimiento sea diferente. A pesar de que en páginas anteriores creemos haber demostrado suficientemente nuestra hipótesis (la Casa de Hippolytus es la sede de una agrupación colegial vinculada a una fundación y un recinto funerario de los Anios) nos consideramos también obligados a responder expresamente a los argumentos de la citada autora. 
En primer lugar, el trabajo de García-Entero emplea documentación arqueológica sin actualizar: por un lado, publica nuestro viejo plano general de Complutum de 1995 que hemos actualizado totalmente en 2000, recogiéndolo de nuevo en este trabajo. Por otro, su reinterpretación también se apoya en una planta del edificio de Hippolytus al que faltan varios elementos, y que sin embargo está actualizado desde 1999: la planta está incompleta en la zona del jardín (faltan varias exedras) y en el sector termal, del que está ausente una parte significativa de los restos, lo que, como veremos, motiva que su lectura del mismo resulte equivocada. Del mismo modo, la realización de un análisis pormenorizado como el suyo es difícil que pueda efectuarse con éxito exclusivamente sobre unos restos musealizados, que tienen siempre un contenido didáctico. Más aún, cuando los restos arqueológicos se contemplan desde lejos, mediante una pasarela. Nos atrevemos a proponer que la autora hubiera debido consultar la abundantísima documentación arqueológica de todo tipo que existe, producto del trabajo de un equipo pluridisciplinar durante varios años, y que constituye la información de primera mano.

En segundo lugar, al no utilizar García-Entero la documentación procedente de la excavación, su lectura de la zona termal no es exacta (García-Entero, 2004, pp. 148 y ss; especialmente, f. 3). Así, en la sala abovedada vinculada a la fachada norte, que ella interpreta como un apodyterium, la autora quiere ver un vano al sur, que la comunicaría con el patio central / frigidarium. Este vano (cuya existencia sería efectivamente útil para apoyar la lectura como apodyterium) simplemente no existe, y esto es un hecho, más allá de interpretaciones de tipo alguno: el muro sur es ciego, y los dos vanos documentados (que aún hoy se pueden ver en el yacimiento) son uno al este y otro al oeste. La sala abovedada tiene accesos sólo desde las dos entradas al edificio, a las que además comunica: las fauces y el pórtico noroccidental, y ninguno al frigidarium. Un segundo error se manifiesta en la descripción que García-Entero realiza del sector caliente de las termas. En la sala longitudinal oriental, anexa y paralela a la occidental, la autora propone unas dimensiones con una longitud aproximada del 50\% de esta, pero en realidad ambas tienen la misma longitud (el lector interesado puede comparar el referido plano de García-Entero con la planta dibujada en la excavación, y que publicamos en páginas precedentes). La autora quiere ver una sudatio, y recogemos su argumentación (p. 152): "La sala recibía el calor directamente desde el praefurnium ubicado en su lado meridional, circunstancia que ha motivado nuestra interpretación de la estancia como sudatio“. Argumentación incorrecta, porque realmente en el lado meridional de la sala propuesta como sudatio lo que existe es otra sala termal, y en este caso hay sólidos elementos en la infraestructura que obligan a esta lectura: la sala, abovedada y longitudinal, se compartimenta en dos ambientes, uno al norte y otro al sur. El praefurnium está al sur de este ambiente más meridional. Por otro lado, y aunque la argumentación se apoye sobre una descripción incorrecta, nosotros si creemos que existe una zona con la función de sudatio en esta parte del edificio, cuyo estudio no vamos a desarrollar aquí.

En tercer lugar, García-Entero no ha utilizado determinada documentación que es fundamental para comprender la Casa de Hippolytus y su función, y que esta vez no se refiere a las estructuras excavadas entre 1991 y 1996, sino a su entorno y a los datos que proceden de análisis complementarios. El empleo de esta documentación, que nosotros si hemos usado en las páginas precedentes, plantea interrogantes que sólo se responden considerando que la Casa de Hippolytus es algo más complejo que unas termas suburbanas, y además descarta algunas otras posibles hipótesis (concretamente, descarta que exista una domus suburbana a la que el espacio termal de la Casa de Hippolytus se encuentre anexo). Así, en el trabajo de García-Entero no existen referencias, o son muy someras y la autora no los relaciona con el yacimiento, a los datos historiográficos, epigráficos y a los análisis de fauna de mamíferos y aves realizados, así como a los estudios arqueobotánicos efectuados sobre semillas, pólenes y fitolitos. Falta, por tanto, una masa de documentos existentes que la Arqueología moderna no puede ni debe ignorar. Especialmente nos sorprende que no exista una sola mención al mausoleo de los Anios, vinculado con la Casa de Hippolytus (nada menos que el lugar donde se entierra la misma familia que construye la casa), de cuya excavación en 1881, rescatada recientemente de un relativo olvido gracias al trabajo de Vallejo, 2005, pp. 79 y ss, hay muchos detalles que son conocidos tradicionalmente, porque gran parte de los materiales recuperados se exhibieron a finales del siglo XIX en un Museo Arqueológico Complutense ubicado en el Archivo General Central, porque alguna documentación relativa a los mismos y a su hallazgo existen todavía en el Archivo del Gabinete de Antigüedades de la Real Academia de la Historia, y porque incluso algunos fueron trasladados a partir de 1900 al Museo Arqueológico Nacional, donde aún se encuentran. De hecho la pieza principal, un ara votiva dedicada a Hércules por Gayo Anio y Magia Atta, ha sido publicada en repetidas ocasiones (en general, ver CIL II 5855), desde el Marqués de Monsalud, en 1899, hasta Knapp, 1992. Con envidiable intuición, este autor ya apuntaba, antes que nosotros, la alta probabilidad de que el altar tuviese relación con la cercanía de una congregación de culto a este dios, como las realizadas por agrupaciones de tipo colegial (aún no se había excavado por cierto la Casa de Hippolytus). 
Igualmente nos sorprende que García-Entero no valore la singularidad de uno de los elementos arqueológicos más importantes del yacimiento: el jardín orientalizante. En sus notas 28 y 29 se refiere a él y a sus exedras como de características “...harto habituales...”). En realidad este jardín es hoy por hoy un unicum de la Arqueología Española, y hasta el momento el único jardín romano en sentido estricto de nuestro país (y de gran parte de Europa, sobre todo si excluimos los fabulosos restos de la Bahía de Nápoles) reconstruible con datos arqueológicos precisos, y del que conocemos la fauna, la vegetación, la topografía, parte de la iconografía asociada y la arquitectura. Este es un proyecto muy complejo, al que hemos hecho referencia en nuestro artículo precedente, y creemos que los implicados, especialistas en su mayor parte en jardinería de la Antigüedad, han abordado el tema con rigor y seriedad que contradicen esa supuesta vulgaridad de los restos complutenses. No conocemos ningún otro yacimiento interpretable como jardín o campo de cultivo con tal abundancia de datos tan variados, ni que ofrezcan una lectura tan extraordinaria (a excepción hecha, repetimos, de los ubicados en la Bahía de Nápoles).

En cuarto lugar, y por último, la interpretación propuesta por García-Entero ("un complejo termal suburbano, concretamente un balneum relacionado con una mansión extramuros") es sencillamente imposible porque no existe tal mansión, sólo existe la Casa de
Hippolytus, es decir el conjunto de termas, zona de culto y jardín. Esto se comprueba consultando por un lado los datos arqueológicos proporcionados por las numerosas construcciones modernas existentes en torno a la Casa de Hippolytus, situada en plena zona de expansión urbana de Alcalá, y por tanto rodeada de edificaciones donde se ha realizado supervisión arqueológica, por otro la documentación historiográfica que existe sobre la zona. La Casa de Hippolytus se encuentra inmersa en la Segunda Ciudad Polideportiva de Alcalá de Henares. Su construcción fue supervisada arqueológicamente en una primera fase en 1987 por Francisco Ardanaz Arranz, con resultados negativos a pesar de que se movieron varias decenas de miles de $\mathrm{m}^{3}$. Nosotros mismos supervisamos, en 1991 y 1992, los movimientos de tierra de la segunda fase. Fruto de esa supervisión apareció sólo la Casa de Hippolytus, y fue excavada, restaurada y musealizada, en una operación hasta la fecha única en la Comunidad de Madrid. Por tanto, no hay más restos arqueológicos asociados. La mansión de García-Entero, la domus suburbana, a la que además, y habida cuenta de la calidad de las termas que la autora quiere atribuirle, habría que suponer un porte muy relevante en sus técnicas constructivas, materiales decorativos, ajuares, etc., sencillamente no está.

Recibido el 15-06-06

Aceptado el 10-09-06 